NIPER-635

Distribution Category UC-122

The Effect of Polymer-Surfactant Interaction on the Rheological Properties of Surfactant Enhanced Alkaline Flooding Formulations

Topical Report

By

Troy R. French

Charles B. Josephson

NIPER--635

DE93 000118

February 1993

Work Performed Under Cooperative Agreement No. DE-FC22-83FE60149

Prepared for

U.S. Department of Energy

Assistant Secretary for Fossil Energy

Thomas B. Reid, Project Manager

Bartlesville Project Office

P. O. Box 1398

Bartlesville, OK 74005

Prepared by

IIT Research Institute

National Institute for Petroleum and Energy Research

P.O. Box 2128

Bartlesville, OK 74005 


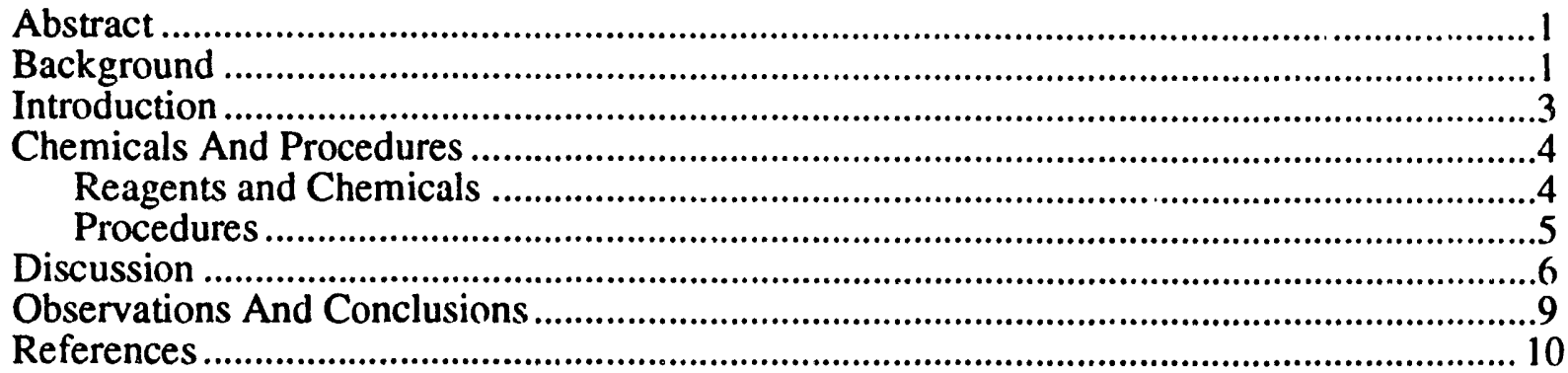

\section{TABLES}

1. Observations of interactions between several polymers, surfactants, and brines .......... 12

2. Mixtures of polymer, surfactant, and brines periodically monitored for changes in $\mathrm{pH}$ and viscosity

\section{ILLUSTRATIONS}

1. Interfacial tension between $0.5 \%$ Chevron XP-100 surfactant, $\mathrm{NaCl}$, and Hepler (KS) crude oil, $23^{\circ} \mathrm{C}$.

2. Viscosity of non-alkaline mixtures of $2,000 \mathrm{ppm}$ Alcoflood 1135 polymer and $\mathrm{NaCl}, 11.5 \mathrm{sec}^{-1}, 23^{\circ} \mathrm{C}$.

3. Viscosity of alkaline mixtures of $2,000 \mathrm{ppm}$ Alcoflood 1135 polymer and $\mathrm{NaCl}, 11.5 \mathrm{sec}^{-1}, 23^{\circ} \mathrm{C}$.

4. Viscosity of $2,000 \mathrm{ppm}$ Alcoflood 1135 polymer in $0.4 \% \mathrm{NaCl}, \mathrm{pH} 5.74$, $23^{\circ} \mathrm{C}$

5. Viscosity of $2,000 \mathrm{ppm}$ Alcoflood 1135 polymer in $0.4 \% \mathrm{NaCl}, \mathrm{pH}$ $10.43,23^{\circ} \mathrm{C}$.

6. Viscosity of $2,000 \mathrm{ppm}$ Alcoflood 1135 polymer in $1.2 \% \mathrm{NaCl}, \mathrm{pH}$ $5.60,23^{\circ} \mathrm{C}$.

7. Viscosity of $2,000 \mathrm{ppm}$ Alcoflood 1135 polymer in $1.2 \% \mathrm{NaCl}, \mathrm{pH}$ $10.50,23^{\circ} \mathrm{C}$.

8. The $\mathrm{pH}$ of mixtures of Alcoflood 1135 polymer and Chevron XP-100 surfactant in $0.4 \% \mathrm{NaCl}$.

9. The $\mathrm{pH}$ of mixtures of Alcoflood 1135 polyraer and Chevron XP-100 surfactant in $1.2 \% \mathrm{NaCl}$.

10. Viscosity of $2,000 \mathrm{ppm}$ Alcoflood 1135 polymer and $0.5 \%$ Chevron $\mathrm{XP}-100$ surfactant in $0.4 \% \mathrm{NaCl}, \mathrm{pH} 7.04,23^{\circ} \mathrm{C}$.

11. Viscosity of $2,000 \mathrm{ppm}$ Alcoflood 1135 polymer and $0.5 \%$ Chevron $\mathrm{XP}-100$ surfactant in $0.4 \% \mathrm{NaCl}, \mathrm{pH} 10.70,23^{\circ} \mathrm{C}$.

12. Viscosity of $2,000 \mathrm{ppm}$ Alcoflood 1135 polymer and $0.5 \%$ Chevron $\mathrm{XP}-100$ surfactant in $1.2 \% \mathrm{NaCl}, \mathrm{pH} 6.88,23^{\circ} \mathrm{C}$. 


\section{TABLES OF CONTENTS (CONTINUED)}

13. Viscosity of $2,000 \mathrm{ppm}$ Alcoflood 1135 polymer and $0.5 \%$ Chevron

XP-100 surfactant in $1.2 \% \mathrm{NaCl}, \mathrm{pH} 10.77,23^{\circ} \mathrm{C}$

14. Viscosity of $2,000 \mathrm{ppm}$ Alcoflood 1135 polymer, and $0.5 \%$ Chevron $\mathrm{XP}-100$ surfactant in $0.4 \% \mathrm{NaCl}, \mathrm{pH} 10.70,11.5 \mathrm{sec}^{-1}, 23^{\circ} \mathrm{C}$.

15. Viscosity of $2,000 \mathrm{ppm}$ Alcoflood 1135 polymer, $0.5 \%$ Chevron XP-100 surfactant, and $0.1 \%$ Hepler (KS) crude oil in $0.4 \% \mathrm{NaCl}$, $\mathrm{pH} 7.07,23^{\circ} \mathrm{C}$

16. Viscosity of $2,000 \mathrm{ppm}$ Alcoflood 1135 polymer, $0.5 \%$ Chevron XP-100 surfactarn, and $0.1 \%$ Hepler (KS) crude oil in $0.4 \% \mathrm{NaCl}$, pH $10.73,23^{\circ} \mathrm{C}$.

17. Viscosity of $2,000 \mathrm{ppm}$ Alcoflood 1135 polymer, $0.5 \%$ Chevron XP-100 surfactant, and $0.1 \%$ Hepler (KS) crude oil in $1.2 \% \mathrm{NaCl}$, $\mathrm{pH} 6.87,23^{\circ} \mathrm{C}$.

18. Viscosity of $2,000 \mathrm{ppm}$ Alcoflood 1135 polymer, $0.5 \%$ Chevron $X$ P-100 surfactant, and $0.1 \%$ Hepler (KS) crude oil in $1.2 \% \mathrm{NaCl}$, $\mathrm{pH} 10.7923^{\circ} \mathrm{C}$. 


\title{
THE EFFECT OF POLYMER-SURFACTANT INTERACTION ON THE RHEOLOGICAL PROPERTIES OF SURFACTANT-ENHANCED ALKALINE FLOODING FORMULATIONS
}

by

Troy R. French and Charles B. Josephson

\begin{abstract}
Surfactant-enhanced, lower $\mathrm{pH}$ (weak) alkaline chemicals are effective for mobilizing residual oil. Polymer is used for mobility control because if mobility control is lost, then oil recovery is reduced. The ability to maintain mobility control during surfactant-alkaline flooding can be adversely affected by chemical interaction. In this work, interaction between polymers and surfactants was shown to be affected by $\mathrm{pH}$, ionic strength, crude oil, and the properties of the polymers and surfactants. Polymer-surfactant interaction (phase separation, precipitation, and viscosity loss) occurred between most of the polymers and surfactants that were tested. Polymer-surfactant interaction is difficult to eliminate, and no method was found for completely eliminating interaction.
\end{abstract}

Polymer-surfactant interaction occurred at optimal salinity and below optimal salinity. Polymer-surfactant interaction had an adverse effect on polymer rheology; however, the adverse effect of interaction on polymer rheology was lessened when oil was present. Increasing the $\mathrm{pH}$ of chemical systems further reduced the adverse effects of interaction on polymer rheology.

This work was performed for the Department of Energy and represents milestone 5, project BE4B in the FY92 Annual Research Plan.

\section{BACKGROUND}

Production from many of the onshore oil reservoirs in the United States has declined to such low levels that much secondary production is no longer economic. Even though large amounts of crude oil remain in place, many of these reservoirs have been waterflooded to high water-to-oil ratios and will soon be abandoned unless cost-effective enhanced oil recovery (EOR) methods are developed. Surfactant-enhanced alkaline flooding, a technology developed in the past 10 years, is a potentially cost-effective method for recovery of a significant quanity of the remaining oil. 1

Surfactant-enhanced alkaline flooding formulations with weak alkaline agents have great potential for some reservoirs. These alkaline formulations react less with reservoir minerals than 
other chemicals and facilitate the use of low concentrations of surfactants because surfactant adsorption is reduced in the presence of alkaline agents. Moderately basic alkaline chemicals, such as sodium carbonate and sodium bicarbonate, are also effective for mobilizing residual oil when relatively low concentrations of surfactant are added to the formulation. ${ }^{2}$

Strong alkalis such as sodium hydroxide and sodium orthosilicate are very effective for mobilizing residual oil in laboratory corefloods, but fundamental research on the reaction kinetics of alkaline formulations with reservoir minerals has indicated that it is nearly impossible to prevent the deleterious reactions that occur when strongly alkaline chemical formulations are injected into reservoir formations. ${ }^{3-4}$ This is the primary reason why many field projects conducted by major oil companies have failed. In some cases, oil production has actually declined as a result of alkaline flooding with strong alkalis. 5

This work led to investigations of milder alkaline agents that are less reactive with reservoir rocks. Initial studies on formulations using sodium carbonate and sodium bicarbonate indicated that the displacement efficiency in corefloods was much less with certain crude oils than that obtainable with highly alkaline chemicals such as sodium hydroxide and sodium orthosilicate. Fundamental research on coalescence phenomena and dynamic interfacial tension behavior indicated that addition of small amounts of synthetic surfactants to moderately alkaline formulations significantly improved the properties of these chemical systems. The efficacy of these surfactant-enhanced alkaline flooding formulations was subsequently verified in oil displacement tests in cores. ${ }^{1}$

In recent years, there has also been some field testing of surfactant-enhanced alkaline flooding. Most of the field activity has been in Wyoming, Louisiana, and Texas.6-7 Initial results from field tests have been promising, but surfactant-enhanced alkaline is not yet a commercial-scale reality, and the objective of Project BE4B is to help develop cost-effective and efficient surfactant-enhanced alkaline chemical flooding formulations and share this information with the petroleum industry.

Initial investment costs for purchasing chemicals for injected formulations have been a significant economic constraint that has hindered commercial applications of many chemical flooding technologies. Surfactant-enhanced alkaline flooding formulations are potentially more cost-effective than some other flooding methods because the cost of alkaline chemicals is comparatively low. The key to obtaining favorable economics is a synergism between alkali, surfactant, and oil that results in mobilization of some crude oils at greatly reduced surfactant 
concentrations. Another favorable property of surfactant-enhanced alkaline systems is reduced loss of surfactant onto reservoir rock by precipitation and adsorption.

\section{INTRODUCTION}

The objective of Project BE4B is to develop cost-effective and efficient chemical flonding formulations using surfactant-enhanced, lower $\mathrm{pH}$ (weak) alkaline chemical systems. It has been shown previously that these chemical systems can be effective in mobilizing residual oil when relatively low concentrations of surfactant are used in the formulation. Several strategies have been suggested for applying surfactant-enhanced alkaline flooding. ${ }^{8-11}$ Some examples are (1) a combination of alkali, surfactant, and polymer into a single slug followed by more polymer, (2) a combination of alkali and surfactant into a single slug, followed by polymer, (3) pre-injection of alkali to condition the reservoir, (4) surfactant followed by alkaline polymer, (5) injection of oil soluble acids followed by alkali, and (6) various injection strategies that utilize surfactant gradients.

Some results obtained from oil recovery tests conducted at NIPER are as follows:

1. Oil recovery was highest when alkaline surfactant was followed by polymer.

2. Oil recovery was only slightly decreased when the alkali, surfactant, and polymer were simultaneously injected (mixed in single slug), and oil production occurred faster.

3. Oil recovery was significantly reduced when surfactant was followed with alkaline polymer.

4. Oil recovery was lowest when surfactant was followed by polymer and there was no alkali in any of the injected solutions.

In all four cases, polymer was used for mobility control. If mobility control is lost, then oil recovery is further reduced. The ability to maintain mobility control during surfactant-alkaline flooding is more strongly affected by chemical interactions than is commonly believed. ${ }^{12-16}$ Although considerable research has been conducted on this subject, the results of that research do not now appear to be common knowledge among many operators who are unaware of the potential chemical interactions that might affect an EOR project. Many types of chemical interactions are possible, and when chemical flooding systems are designed, the effects of chemical interactions may be overlooked. Some interactions may have negligible effect in laboratory corefloods; however, all chemical interactions have the potential to affect the outcome of field projects. 
For economic reasons, it may be advantageous to inject surfactant, polymer, and alkali as a single slug. Chemical interactions can occur between any of the chemicals contained in the single slug. In a short coreflood, interactions that occur between the polymer and other chemicals can be minimized by injecting the polymer as a separate slug, rather than mixing the polymer in the same slug that contains surfactant and alkali. In this procedure, an operator can decrease the total amount of polymer used, which is economically favorable, because the ionic strength of the polymer slug can be less than the ionic strength of the alkaline slug. However, segregation of polymer in a separate slug will not eliminate interaction with chemicals in a preceding chemical slug. In the absence of adsorption, polymer molecules will propagate through reservoir rock at a faster rate than small molecules such as water. This is attributed to a phenomenon called inaccessible pore volume (IPV) which can be significant -- 35\% PV is not uncommon. ${ }^{15,17}$ Because of IPV, polymer will invade and dilute the chemical slug ahead. This will affect the mobility and stability of the chemical slug and the required volume of mobility buffer bank. It also means that if there are incompatibilities between the polymer and constituents in the lead slug, then chemical interactions will not be eliminated by injecting polymer as a separate slug.

The interactions that can occur during surfactant-enhanced alkaline flooding are complex. Some of the parameters are $\mathrm{pH}$ level, ionic strength, polymer properties, cosurfactant (alcohols) properties, and surfactant properties. The presence of crude oil may also affect interaction, as can other chemicals. ${ }^{12}$ At least six types of surfactant-polymer complexes have been described, 12-16 and the interactions that occur between polymers and surfactants could be the most significant of the possible interactions that can occur during surfactant-enhanced alkaline flooding. Polymer-surfactant interaction was the focus of this work. Rheological properties of polymer solutions were monitored over a long period of time in the presence of surfactants, at different $\mathrm{pH}$ levels, and in the presence of crude oil.

\section{CHEMICALS AND PROCEDURES}

\section{Reagents and Chemicals}

Hepler (KS) Tucker Sand (class I reservoir) crude oil Surfactants:

Chevron Chaser XP-100, an anionic surfactant, mol wt $=434$

Chevron Chaser CF-100, an experimental anionic surfactant

Stepan Petrostep B-110, an anionic surfactant, $\mathrm{mol} w t=500$

Stepan Petrostep B-105 an anionic surfactant mixture, mol wt about 424 
Shell Neodol 25-9, ethoxylated alcohol, $\mathrm{mol} \mathrm{wt}=610$

Polymers:

Pfizer Flopaam 3230E, a low-molecular-weight partially hydrolyzed emulsion polyacrylamide, $\mathrm{mol} w \mathrm{t}=7-8 \times 10^{6}$

Pfizer Flopaam 3230S, a low-molecular-weight partially hydrolyzed solid polyacrylamide, $\mathrm{mol} \mathrm{wt}=7-8 \times 10^{6}$

Pfizer Flocon 4800CX, a biopolymer

Allied Colloids Alcoflood 1135, a medium-molecular-weight partially

hydrolyzed solid polyacrylamide polymer

Alkalis:

Sodium carbonate, analytical reagent

Sodium bicarbonate, certified ACS

Sodium hydroxide, certified ACS

Sodium tripolyphosphate (STPP), technical

Make-up water:

Deionized water (DIW)

Hepler supply well water:

$\begin{array}{lrl}\text { Sodium and potassium } & 830 & \mathrm{mg} / \mathrm{L} \\ \text { Chlorides } & 908 & \mathrm{mg} / \mathrm{L} \\ \text { Calcium and Magnesium } & 21 & \mathrm{mg} / \mathrm{L} \\ \text { Bicarbonate } & 720 & \mathrm{mg} / \mathrm{L} \\ \text { TDS } & 2,483 & \mathrm{mg} / \mathrm{L} \\ \text { pH } & 7.9 & \end{array}$

\section{Procedures}

Rheology and $\mathrm{pH}$ of mixtures were periodically monitored for 191 days. All compositions are given as weight per volume, and each solution contained $300 \mathrm{ppm}$ formaldehyde as a preservative. A Contraves low-shear viscometer was used for initial measurements of viscosity. Because of mechanical problems with the Contraves, the later measurements were made with a Brookfield Model LVT-C/P $1.565^{\circ}$ cone and plate viscometer. Samples were aged at room temperature and viscosity was measured at $23^{\circ} \mathrm{C}$. Rheological measurements were displayed graphically in 3-dimensions using a computer program that was specifically designed for 3-dimensional plots. An Orion Model 601 digital $\mathrm{pH}$ meter was used for $\mathrm{pH}$ measurements. Samples were monitored visually for phase separation, cloudiness, and precipitation. 
Interfacial properties of selected systems were measured with a University of Texas spinning drop interfacial tensiometer. Transient (dynamic) IFT behavior was monitored over a time interval of several hours.

\section{DISCUSSION}

Interactions that occur between alkaline chemicals, polymers, surfactants, and cosurfactants are complex. Interactions have been shown to be affected by $\mathrm{pH}$ level, ionic strength, crude oil, and the properties of polymers, surfactants and co-surfactants. Additionally, reservoir rock may play a significant role. The interactions that occur between polymers and surfactants under alkaline conditions are very significant, and are the focus of this discussion. Table 1 presents the results of visual observations from a series of interaction tests. Many of these systems were mixed in water from a water supply well in Hepler (KS) oil field where a field test is planned. Many of the experiments were performed after it was observed that interactions occurred between polymers and surfactants in chemical systems that produced good oil recovery in laboratory corefloods. ${ }^{18}$

Polymers used for the tests shown in Table 1 were Pfizer Flocon 4800 CX biopolymer, Pfizer Flopaam 3230E (emulsion polyacrylamide), Pfizer Flopaam 3230S (solid polyacrylamide), and Allied Colloids Alcoflood 1135, which is a solid polyacrylamide. Alkalis were sodium bicarbonate, sodium carbonate, and mixtures of sodium bicarbonate and sodium carbonate.

The surfactants were Shell Neodol 25-9 nonionic surfactant, a mixture of Stepan Petrostep B series anionic surfactants, and Chevron anionic surfactants Chaser XP-100 and CF100. The anionic surfactants supplied by Chevron Chemical Company are of special interest because they are expected to be used in the field test mentioned above.

The results in Table 1 show that some phase separation occurs when the emulsion polyacrylamides are dispersed in brine. Biopolymers dispersed into brines as hazy, stable solutions, and the solid polyacrylamides, $3230 \mathrm{~S}$ and 1135 dispersed as clear, stable solutions.

Neodol 25-9, a nonionic ethoxylated alcohol, dispersed into brine as a clear solution. Anionic surfactants, Stepan B series, XP-100, and CF-100, dispersed as stable, cloudy suspensions, except at high ionic strengths where they became insoluble.

When surfactants and polymers were dispersed into solutions together, phase separation and precipitation usually occurred. The exception was Neodol 25-9 (nonionic), which gave 
stable, hazy solutions with biopolymer and only a trace of precipitate with polyacrylamide polymer. Combinations of anionic surfactants with polyacrylamides always resulted in phase separation and/or precipitation. Precipitation of anionic surfactants occurred more slowly with biopolymer, but the amount of precipitate was about the same as that for polyacrylamides.

When surfactants and polymers were dispersed into aqueous solutions and then contacted with Hepler crude oil, the interaction between surfactant and polymer still existed, but was much different from the interaction that was observed when crude oil was absent. With XP-100 surfactant and $3230 \mathrm{~S}$ polymer, the emulsion that was formed showed less phase separation when oil was present. This was most apparent at low XP-100 concentrations.

Interactions between polymers and surfactants are of special interest when the conditions of salinity (ionic strength) are such that optimum IFT behavior occurs between the surfactant mixture and a particular crude oil. For this reason, the surfactant-enhanced alkaline mixtures presented in Table 1 are for chemical systems that were optimized to give low IFT values with specific crude oils. The Neodol 25-9 chemical system was optimized with crude oil from Wilmington (CA) oil field. ${ }^{19}$ The XP-100, CF-100, and Petrostep surfactants were optimized with Hepler produced oil.

One chemical system was selected for further study of the effects of polymer-surfactant interaction on rheology. The system selected contained $0.5 \%$ XP-100 surfactant and sodium chloride. The dynamic IFT between this chemical system and Hepler oil is shown in Fig. 1. Optimum salinity (lowest IFT) occurred with $1.2 \% \mathrm{NaCl}$. With $1.2 \% \mathrm{NaCl}, \mathrm{XP}-100$ solutions were stable, hazy dispersions.

The mixtures shown in Table 2 contain $0.4,0.6$, or $1.2 \% \mathrm{NaCl}$. $\mathrm{NaCl}$ concentrations of 0.4 and $0.6 \%$ are below optimum and $1.2 \%$ is equal to optimum salinity. Adjustment of pH was accomplished with sodium hydroxide, a strong alkali. Weak, buffered alkalis have properties that are advantageous for field use. ${ }^{2}$ For these studies, however, the strong alkali is more useful because $\mathrm{pH}$ can be adjusted with the addition of small amounts of the strong alkali; therefore, the ionic strength is changed only very little during $\mathrm{pH}$ adjustment. The polymer used for the tests was Alcoflood 1135, a medium-molecular-weight anionic polymer which is furnished in solid form. Alcoflood 1135 is a partially hydrolyzed polyacrylamide.

The $\mathrm{pH}$, viscosity, and appearance of the mixtures shown in Table 2 were monitored periodically for 191 days. The detrimental effects of salt solutions on the rheological properties of polyacrylamide polymers is well known. The effects of salinity and shear rate on apparent viscosity are shown in Fig. 2 (pH less than 7) and Fig. 3 (pH greater than 10). The pH level had 
negligible effect on the rate of viscosity reduction as salinity was increased. Some downward drift in viscosity with time occurred at both $\mathrm{pH}$ levels.

The rates of change in apparent polymer viscosity with time are shown in Figs. 4, 5, 6, and 7. Figures 4 and 5 show the results of periodic measurements of polymer solutions at $\mathrm{pH}$ 5.74 and $\mathrm{pH} 10.43$, respectively, in $0.4 \% \mathrm{NaCl}$. At pH 5.74, there was a slight increase in viscosity at early time, followed by decreased viscosity that became nearly stable after 50 days. Overall, viscosity decreased from 46 to $38 \mathrm{cP}$ over 191 days at low shear rate. At pH 10.43, there was also an initial increase in viscosity that was followed by a relatively stable value of viscosity. Overall, viscosity decreased from 51 to $44 \mathrm{cP}$.

For comparison, Figs. 6 and 7 show the results of periodic measurements of polymer solutions at $\mathrm{pH} 5.60$ and $\mathrm{pH} 10.50$, respectively, in $1.2 \% \mathrm{NaCl}$. At $\mathrm{pH} 5.60$, there was a slight increase in viscosity at early time followed by a decrease in viscosity until about 60 days, after which viscosity was relatively stable. Overall, viscosity decreased from 21 to $18 \mathrm{cP}$ at low shear rate. For $\mathrm{pH} 10.50$, behavior was very similar, with an overall viscosity decrease from 23 to 19 cP.

The $\mathrm{pH}$ levels of polymer solutions with $\mathrm{pH}$ values of 5.74 and 5.60 were unaltered, i.e. these $\mathrm{pH}$ levels were the $\mathrm{pH}$ values that resulted from mixing the polymer without addition of any chemicals to alter the naturally occurring $\mathrm{pH}$. The $\mathrm{pH}$ levels of the polymer solutions with $\mathrm{pH}$ values of 10.43 and 10.50 were adjusted by addition of sodium hydroxide. Adjusting the $\mathrm{pH}$ of these polymer solutions by addition of sodium hydroxide resulted in a $10 \%$ increase in apparent viscosity at low shear rate. Otherwise, the rate of change of viscosity over 191 days was not much different for the four polymer mixtures.

The $\mathrm{pH}$ changes in these solutions are shown in Figs. 8 and 9. The pH values of the two polymer mixtures that were below $\mathrm{pH} 7$ were virtually unchanged over the entire time of periodic measurement, whereas the $\mathrm{pH}$ values of the alkaline polymer mixtures declined over the entire period of measurement. It is possible that some loss of viscosity was due to hydrolysis occurring in these polymer mixtures. ${ }^{20}$ All of the polymer mixtures exhibited a very slow degradation of viscosity.

The rates of change in apparent viscosity for mixtures that contain polymer and surfactant are shown in Figs. 10,11, 12, and 13. Figures 10 and 11 show the results of periodic measurements of polymer - surfactant mixtures at $\mathrm{pH} 7.04$ and 10.70 , respectively, in $0.4 \%$ $\mathrm{NaCl}$. At $\mathrm{pH} \mathrm{7.04,} \mathrm{viscosity} \mathrm{decreased} \mathrm{sharply} \mathrm{for} 50$ days and continued to decline over the entire time interval. Overall, viscosicy decreased from 60 to $19 \mathrm{cP}$ at low shear rate, a decrease 
of $68 \%$. For $\mathrm{pH} 10.70$, behavior was very similar. After a slight initial increase in viscosity at early time, viscosity decreased sharply during the first 40 days of measurements. Overall, viscosity decreased from 58 to $27 \mathrm{cP}$ at low shear rate, a decrease of 54\%. A slight increase in viscosity at early time was masured for all of the mixtures that contained polymer and surfactant. A typical example of this is shown more clearly in Fig. 14.

For comparison, Figs. 12 and 13 show the results of periodic measurements of polymersu. factant mixtures at $\mathrm{pH} 6.88$ and 10.77 , respectively, in $1.2 \% \mathrm{NaCl}$. At pH 6.88, a sharp decrease in viscosity occurred over the first 40 days. Viscosity then increased slightly, followed by a gradual decline over the remainder of the time interval. Overall, viscosity decreased from 25 to $8 \mathrm{cP}$, a decrease of $68 \%$. For $\mathrm{pH} 10.77$, behavior was very similar with an overall decrease in viscosity from 24 to $9 \mathrm{cP}$, a decrease of $60 \%$. Viscosity decrease was much greater for these

- polymer-surfactc.it mixtures than for the polymer solutions discussed above.

Viscosity changes for the four polymer-surfactant mixtures were quite similar, except for the second occurrence of viscosity increase in both of the graphs for $1.2 \% \mathrm{NaCl}$. In 0.4 and $1.2 \%$ $\mathrm{NaCl}$, the viscosity of the alkaline mixtures was about the same as for the non-alkaline mixtures. The changes that occurred in $\mathrm{pH}$, shown in Figs. 8 and 9, are about the same as was observed for polymer solutions that did not contain surfactant, except that the $\mathrm{pH}$ of the solutions without $\mathrm{pH}$ adjustment are nearer to $\mathrm{pH} 7$, because XP-100 surfactant is slightly alkaline.

The rates of change in apparent polymer viscosity for polymer-surfactant-oil mixtures are shown in Figs. 15 through 18. Figures 15 and 16 show the results of periodic measurements of polymer-surfactant-oil mixtures at $\mathrm{pH} 7.07$ and $\mathrm{pH} 10.73$, respectively, in $0.4 \% \mathrm{NaCl}$. At both $\mathrm{pH}$ values, initial viscosity was lower and the rate of viscosity decrease was less steep than for the previously discussed mixtures of polymer-surfactant mixtures. Polymer-surfactant-oil mixtures were more homogeneous in appearance and there was less scatter in measurements. At $\mathrm{pH} 7.07$, viscosity decreased from 50 to $19 \mathrm{cP}$ over the time interval, an overall decrease of $62 \%$. At $\mathrm{pH} 10.73$, viscosity decreased from 52 to $40 \mathrm{cP}$, an overall decrease of only $23 \%$.

In $1.2 \% \mathrm{NaCl}$ (Figs. 17 and 18), similar results were obtained for polymer-surfactant-oil mixtures. At $\mathrm{pH} 6.87$, overall viscosity decrease at low shear rate was from 20 to $8 \mathrm{cP}$, or $60 \%$. At $\mathrm{pH} 10.79$, viscosity decrease was from 25 to $15 \mathrm{cP}$, or $40 \%$.

\section{OBSERVATIONS AND CONCLUSIONS}

1. Polymer-surfactant interaction can be expected to have an adverse effect on oil recovery, especially when permeability is low. 
2. Polymer-surfactant interaction (phase separation, precipitation, and viscosity loss) occurred between most of the polymers and surfactants that were tested.

3. Polymer-surfactant interaction is difficult to eliminate, and no method was found for completely eliminating interaction.

4. Polymer-surfactant interaction occurred at optimal salinity and below optimal salinity.

5. The magnitude of the interaction was least for non-ionic surfactant and biopolymer.

6. Polymer-surfactant interaction had an adverse effect on polymer rheology.

7. The adverse effect of interaction on polymer rheology was lessened when oil was present.

8. When oil was present, the adverse effect of interaction on polymer rheology was further reduced by increasing $\mathrm{pH}$.

\section{REFERENCES}

1. Peru, D.A. Aqueous Flooding Methods for Tertiary Oil Recovery. U. S. Patent 4,817,715, April 1989.

2. French, T. R. and T. E. Burchfield. Design and Optimization of Alkaline Flooding Formulations. Pres. at the Seventh Joint SPE/DOE Symposium on Enhanced Oil Recovery, Tulsa, OK, April 1990. SPE/DOE paper 20238.

3. Lorenz, P.B. and D.A. Peru. Guidelines Help Select Reservoirs for NaHCO3 EOR. Oil \& Gas J., v. 87, No. 37, Sept. 11, 1989, pp. 53-57.

4. Thomton, S. D. and P. B. Lorenz. Role of Silicate and Aluminate Ions in the Reaction of Sodium Hydroxide with Reservoir Minerals. Pres. at the SPE Int. Symp. on Oilfield Chemistry, San Antonio, TX, Feb. 4 - 6, 1987. SPE paper 16277.

5. Dauben, D. L., R. A. Easterly, and M. M. Western. An Evaluation of the Alkaline Waterflooding Demonstration Project, Ranger Zone Wilmington Field, California. DOE Report DOE/BC/10830-5 (NTTS Order No. DE87001240), May, 1987.

6. Falls, A. H., D. R. Thigpen, and R. C. Nelson. A Field Test of Cosurfactant-Enhanced Alkaline Flooding. Pres at the SPE/DOE Eighth Symposium on Enhanced Oil Recovery in Tulsa, OK, Apr. 22 - 24, 1992. SPE/DOE paper 24117.

7. Meyers, J. J., M. J. Pitts, and K. Wyatt. Alkaline-Surfactant-Polymer Flood of the West Kiehl, Minnelusa Unit. Pres at the SPE/DOE Eighth Symposium on Enhanced Oil Recovery in Tulsa, OK, Apr. 22 - 24, 1992. SPE/DOE paper 24144.

8. Schuler, P. J., R. M. Lemer, and D. L. Kuehne. Improving Chemical Flood Efficiency with Micellar/Alkaline/Polymer Processes. Pres. at the Fifth SPE/DOE Symp. on Enhanced Oil Recovery, Tulsa, OK, Apr. 20-23, 1986. SPE/DOE paper 14934.

9. Krumrine, P. H., J. S. Falcone, Jr., and T. C. Campbell. Surfactant Flonding 1: The Effect of Alkaline Additives on IFT, Surfactant Adsorption, and Recovery Efficiency. Soc. Pet. Eng. J., v. 22, No. 4, August 1982.

10. Krumrine, P. H. and J. S. Falcone, Jr. Surfactant, Polymer, and Alkali Interactions in Chemical Flooding Processes. Pres. at the SPE Int'I Symp. on Oil field and Geothermal Chemistry, Denver, CO, June 1-3, 1983. SPE paper 11778. 
11. French, T. R. and C. B. Josephson. Alkaline Flooding Injection Strategy. DOE Report No. NIPER-563. Sept. 1991.

12. Kalpakci, Bayram. Flow Properties of Surfactant Solutions in Porous Media and Polymer-surfactant Interactions. A Thesis in Chemical Engineering, Pennsylvania State University, Nov. 1981.

13. Shuji, Saito. Polymer-Surfactant Interactions. Chapter 15, Nonionic Surfactants edited by Martin J. Schick. Marcel Dekker, Inc., New York and Basel, 1987, pp. 881-926.

14. Yang, C. Z. Adjustment of Surfactant/Polymer Interaction in Surfactant/Polymer Flooding with Polyelectrolytes. Pres. at the SPE/DOE Fifth Symposium on Enhanced Oil Recovery, Tulsa, OK, April 20-23, 1986. SPE/DOE paper 14931.

15. Trushenski, Scott P. Micellar Flooding: Sulfonate-Polymer Interaction. Improved Oil Recovery by Surfactant and Polymer Flooding (Shah, D. O. and Schecter, R. S., Eds.), Academic Press, New York, 1977, pp. 555-75.

16. Nagarajan, R. On the Nature of Interactions Between Polymers and Surfactants in Dilute Aqueous Solutions. Polym. Prepr. (Am. Chem. Soc., Div. Polym. Chem.), 22(2), pp. 33-8, 51-2, 1981.

17. Gao, H. W., T. R. French, and T. E. Burchfield. Optimai Rheological Characteristics in Dynamic Stability of Polymer Flow Through Porous Media. Pres. at 1988 AICHE Annual Meeting in Washington D. C., Nov. 27 - Dec. 2, 1988.

18. French, Troy R. Surfactant-Enhanced Alkaline Flooding Field Project. DOE Report NIPER-569. Oct. 1991.

19. French, T. R., D. A. Peru, and S. D. Thomton. Low pH Alkaline Chemical Formulations. DOE Report NIPER-375, October 1988.

20. Moens, J. and G. Smets. Alkaline and Acid Hydrolysis of Polyvinylamides. J. Polm. Sci. Vol. XXIII, 1957, pp. 931-48. 
TABLE 1

Observations of Interactions Betiveen Several Polymers, Surfactants, and Brines

\begin{tabular}{|c|c|c|c|}
\hline Brine & Surfactant & Polymer & Observations \\
\hline $1 \% \mathrm{NaCl}$ & - & 3000 ppm Pusher 500 & Clear sol'n \\
\hline $1 \% \mathrm{NaCl}$ & - & $3500 \mathrm{ppm} 4800 \mathrm{CX}$ & Hazy sol'n \\
\hline $1 \% \mathrm{NaCl}$ & - & $3000 \mathrm{ppm} 4800 \mathrm{CX}$ & Hazy sol'n \\
\hline $1 \% \mathrm{NaCl}$ & - & $1000 \mathrm{ppm} 4800 \mathrm{CX}$ & Hazy sol'n \\
\hline $1 \% \mathrm{NaCl}, 0.19 \mathrm{~N} \mathrm{Carbonate} \mathrm{mixture}$ & - & $3500 \mathrm{ppm} 4800 \mathrm{CX}$ & Hazy sol'n \\
\hline $1 \% \mathrm{NaCl}, 0.19 \mathrm{~N}$ Carbonate mixture & $\begin{array}{l}0.25 \% \text { B-1 } 10 \\
0.15 \% \text { B-105 }\end{array}$ & - & Cloudy sol'n \\
\hline $1 \% \mathrm{NaCl}, 0.19 \mathrm{~N}$ Carbonate mixture & $\begin{array}{l}2.031 \% 2 \mathrm{BA}^{1} \\
0.25 \% \mathrm{~B}-110 \\
0.15 \% \mathrm{~B}-105 \\
2.031 \% 2 \mathrm{BA}\end{array}$ & $3500 \mathrm{ppm} 4800 \mathrm{CX}$ & $\begin{array}{l}\text { Hazy sol'n, thicis layer of viscot:s } \\
\text { emulsion at top }\end{array}$ \\
\hline $2 \% \mathrm{NaCl}$ & $\begin{array}{l}0.25 \% \mathrm{~B}-110 \\
0.15 \% \mathrm{~B}-105 \\
2.031 \% 2 \mathrm{BA}\end{array}$ & - & $\begin{array}{l}\text { Hazy sol'n, thick layer of } \\
\text { viscous emulsion at top that } \\
\text { easily disperses }\end{array}$ \\
\hline $\begin{array}{l}2.5 \% \mathrm{NaCl}, 0.19 \mathrm{~N} \text { Carbonate } \\
\text { mixture }\end{array}$ & $0.1 \%$ N25-9 & 2000 ppm $4800 \mathrm{CX}$ & $\begin{array}{l}\text { Hazy sol'n-eventually a thin layer } \\
\text { of ppt separated }\end{array}$ \\
\hline $\begin{array}{l}2.5 \% \mathrm{NaCl}, 0.19 \mathrm{~N} \text { Carbonate } \\
\text { mixture }\end{array}$ & $0.1 \%$ N25-9 & 2000 ppm 1135 & Clear sol'n with trace of ppt \\
\hline $\begin{array}{l}2.5 \% \mathrm{NaCl}, 0.19 \mathrm{~N} \text { Carbonate } \\
\text { mixture }\end{array}$ & - & $2000 \mathrm{ppm} 4800 \mathrm{CX}$ & Hazy sol'n \\
\hline $\begin{array}{l}2.5 \% \mathrm{NaCl}, 0.19 \mathrm{~N} \text { Carbonate } \\
\text { mixture }\end{array}$ & - & 2000 ppm 1135 & Clear sol'n \\
\hline $\begin{array}{l}2.5 \% \mathrm{NaCl}, 0.19 \mathrm{~N} \text { Carbonate } \\
\text { mixture }\end{array}$ & $0.1 \%$ N25-9 & - & Clear sol'n \\
\hline Supply water ${ }^{2}$ & - & $2000 \mathrm{ppm} 3230 \mathrm{E}$ & $\begin{array}{l}\text { Translucent sol'n with thin layer } \\
\text { of white opaque, viscous } \\
\text { emulsion at top }\end{array}$ \\
\hline $\begin{array}{l}\text { Supply water, } 1.6 \% \mathrm{NaHCO}_{3}, 0.5 \% \\
\text { STPP }\end{array}$ & - & 2000 ppm $3230 \mathrm{E}$ & $\begin{array}{l}\text { Translucent sol'n with thin layer } \\
\text { of white opaque, viscous } \\
\text { emulsion at top }\end{array}$ \\
\hline Supply water & - & $1000 \mathrm{ppm} 3230 \mathrm{~S}$ & Clear sol'n \\
\hline Supply water & - & $500 \mathrm{ppm} 3230 \mathrm{~s}$ & Clear sol'n \\
\hline $\begin{array}{l}\text { Supply water, } 1.6 \% \mathrm{NaHCO}_{3}, 0.5 \% \\
\text { STPP }\end{array}$ & $0.5 \%$ XP-100 & $1000 \mathrm{ppm} 4800 \mathrm{CX}$ & $\begin{array}{l}\text { Hazy sol'n, medium layer of } \\
\text { viscous ppt }\end{array}$ \\
\hline $\begin{array}{l}\text { Supply water, } 1.2 \% \mathrm{NaHCO}_{3}, 0.5 \% \\
\text { STPP }\end{array}$ & $0.5 \%$ XP-100 & $2000 \mathrm{ppm} 3230 \mathrm{~S}$ & $\begin{array}{l}\text { Hazy sol'n, thin layer of viscous } \\
\text { ppt }\end{array}$ \\
\hline $\begin{array}{l}\text { Supply water, } 1.2 \% \mathrm{NaHCO}_{3}, 0.5 \% \\
\text { STPP }\end{array}$ & $0.5 \% \times P-100$ & $1000 \mathrm{ppm} 3230 \mathrm{~S}$ & $\begin{array}{l}\text { Hazy sol'n, thin layer of viscous } \\
\text { ppt }\end{array}$ \\
\hline $\begin{array}{l}\text { Supply water, } 1.2 \% \mathrm{NaHCO}_{3}, 0.5 \% \\
\text { STPP }\end{array}$ & $0.5 \%$ CF- 100 & $2000 \mathrm{ppm} 4800 \mathrm{CX}$ & $\begin{array}{l}\text { Hazy sol'n, thick layer of viscous } \\
\text { ppt }\end{array}$ \\
\hline $\begin{array}{l}\text { Supply water, } 1.2 \% \mathrm{NaHCO}_{3}, 0.5 \% \\
\text { STPP }\end{array}$ & $0.5 \%$ CF- 100 & 2000 ppm 1135 & $\begin{array}{l}\text { Hazy sol'n, medium layer of very } \\
\text { viscous ppt }\end{array}$ \\
\hline $\begin{array}{l}\text { Supply water, } 1.2 \% \mathrm{NaHCO}_{3}, 0.5 \% \\
\text { STPP }\end{array}$ & - & 2000 ppm $4800 \mathrm{CX}$ & Hazy sol'n \\
\hline $\begin{array}{l}\text { Supply water, } 1.2 \% \mathrm{NaHCO}_{3}, 0.5 \% \\
\text { STPP }\end{array}$ & - & 2000 ppm 1135 & Clear sol'n \\
\hline
\end{tabular}


TABLE 1 - Continued

Observations of Interactions Between Several Polymers, Surfactants, and Brines

\begin{tabular}{|c|c|c|c|}
\hline Brine & Surfactant & Polymer & Observations \\
\hline $\begin{array}{l}\text { Supply water, } 1.2 \% \mathrm{NaHCO}_{3}, 0.5 \% \\
\text { STPP }\end{array}$ & $0.5 \%$ CF- 100 & 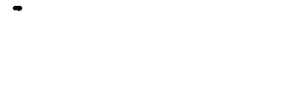 & Translucent sol'n \\
\hline $\begin{array}{l}\text { Supply water, } 1.2 \% \mathrm{NaHCO}_{3}, 0.5 \% \\
\text { STPP }\end{array}$ & $0.5 \%$ CF-100 & $2000 \mathrm{ppm} 4800 \mathrm{CX}$ & $\begin{array}{l}\text { Hazy sol'n, thick layer of viscous } \\
\text { ppt }\end{array}$ \\
\hline $\begin{array}{l}\text { Supply water, } 1.2 \% \mathrm{NaHCO}_{3}, 0.5 \% \\
\text { STPP }\end{array}$ & $0.5 \%$ CF- 100 & $2000 \mathrm{ppm} 1135$ & $\begin{array}{l}\text { Hazy sol'n, thick layer of viscous } \\
\text { ppt }\end{array}$ \\
\hline $\begin{array}{l}\text { Supply water, } 1.2 \% \mathrm{NaHCO}_{3}, 0.5 \% \\
\text { STPP }\end{array}$ & - & 2000 ppm $4800 \mathrm{CX}$ & Hazy sol'n \\
\hline $\begin{array}{l}\text { Supply water, } 1.2 \% \mathrm{NaHCO}_{3}, 0.5 \% \\
\text { STPP }\end{array}$ & - & 2000 ppm 1135 & Clear sol'n \\
\hline $\begin{array}{l}\text { Supply water, } 1.2 \% \mathrm{NaHCO}_{3}, 0.5 \% \\
\text { STPP }\end{array}$ & $0.5 \%$ CF- 100 & - & Translucent sol'n \\
\hline $\begin{array}{l}\text { Supply water, } 1.2 \% \mathrm{NaHCO}_{3}, 0.5 \% \\
\text { STPP }\end{array}$ & $0.2 \%$ CF -100 & 2000 ppm 1135 & $\begin{array}{l}\text { Hazy sol'n, thin layer of viscous } \\
\text { ppt }\end{array}$ \\
\hline $\begin{array}{l}\text { Supply water, } 1.2 \% \mathrm{NaHCO}_{3}, 0.5 \% \\
\text { STPP }\end{array}$ & $0.1 \%$ CF -100 & 2000 ppm 1135 & $\begin{array}{l}\text { Hazy sol'n, thinner layer of } \\
\text { viscous ppt }\end{array}$ \\
\hline $\begin{array}{l}\text { Supply water, } 1.2 \% \mathrm{NaHCO}_{3}, 0.5 \% \\
\text { STPP }\end{array}$ & $0.05 \% \mathrm{CF}-100$ & 2000 ppm 1135 & $\begin{array}{l}\text { Hazy sol'n, thinner layer of } \\
\text { viscous ppt }\end{array}$ \\
\hline $\begin{array}{l}\text { Supply water, } 1.2 \% \mathrm{NaHCO}_{3}, 0.5 \% \\
\text { STPP }\end{array}$ & $0.5 \% \mathrm{XP}-100$ & $2000 \mathrm{ppm} 3230 \mathrm{~S}$ & $\begin{array}{l}\text { Translucent brown sol'n w/thin } \\
\text { layer of dark, visc. ppt and some } \\
\text { dark emulsion at top-eventually } \\
\text { brown sol'n became clear }{ }^{3}\end{array}$ \\
\hline $\begin{array}{l}\text { Supply water, } 1.2 \% \mathrm{NaHCO}_{3}, 0.5 \% \\
\text { STPP }\end{array}$ & $1.0 \%$ XP- 100 & $1200 \mathrm{ppm} 3230 \mathrm{~S}$ & $\begin{array}{l}\text { Translucent sol'n w/ thin layer of } \\
\text { viscous ppt and layer of dark ppt, } \\
\text { oil on top }\end{array}$ \\
\hline
\end{tabular}

1. 2BA is 2-butanol.

2. Supply well water contains $21 \mathrm{ppm}$ divalent cations (2,483 TDS).

3. Sample contains $1000 \mathrm{ppm}$ of Hepler (KS) field crude oil. 
TABLE 2

Mixtures of Polymer, Surfactant, and Brines Periodically Monitored for Changes in pH and Viscosity

\begin{tabular}{|c|c|c|c|c|c|c|}
\hline $\begin{array}{l}\text { Nacl } \\
\text { conc., } \\
\%\end{array}$ & Initial & Final & $\begin{array}{c}\text { Surfactant, } \\
\%\end{array}$ & Polymer & $\begin{array}{c}\text { Oil, } \\
\%\end{array}$ & Results \\
\hline 0.40 & 5.74 & 5.70 & 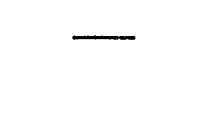 & $\begin{array}{l}2000 \mathrm{ppm} \\
\text { Alcoflood } 1135\end{array}$ & - & $\begin{array}{l}\text { Slight initial increase in } \mu \text {, then decreased } \\
\text { becoming stable after } 50 \text { days. Overall, } \mu \\
\text { decreased from } 46 \text { to } 38 \mathrm{cP} \text {. }\end{array}$ \\
\hline 0.40 & 7.04 & 7.20 & $0.5 \%$ XP-100 & $\begin{array}{l}2000 \mathrm{ppm} \\
\text { Alcoflood } 1135\end{array}$ & - & $\begin{array}{l}\mu \text { decreased sharply for } 50 \text { days and continued } \\
\text { to decline over entire time interval. Overall, } \mu \\
\text { decreased from } 60 \text { to } 19 \mathrm{cP} \text {. }\end{array}$ \\
\hline 0.40 & 7.07 & 7.16 & $0.5 \%$ XP- 100 & $\begin{array}{l}2000 \mathrm{ppm} \\
\text { Alcoflood } 1135\end{array}$ & 0.1 & $\begin{array}{l}\mu \text { gradually decreased over entire time interval. } \\
\text { Very smooth curve. Overall, } \mu \text { decreased from } \\
50 \text { to } 19 \mathrm{cP} \text {. }\end{array}$ \\
\hline 0.40 & 10.43 & 8.22 & - & $\begin{array}{l}2000 \mathrm{ppm} \\
\text { Alcoflood } 1135\end{array}$ & - & $\begin{array}{l}\text { Slight initial increase in } \mu \text {, but relatively stable } \\
\text { over entire time interval. Overall, } \mu \text { decreased } \\
\text { from } 51 \text { to } 44 \mathrm{cP} \text {. }\end{array}$ \\
\hline 0.40 & 11.00 & 10.85 & $0.5 \% \times P-100$ & & - & Stable dispersion. $\mu=1.42 \mathrm{cP} @ 230 \mathrm{sec}^{-1}$ \\
\hline 0.40 & 10.70 & 9.16 & $0.5 \% \times \mathrm{XP}-100$ & $\begin{array}{l}2000 \mathrm{ppm} \\
\text { Alcoflood } 1135\end{array}$ & . & $\begin{array}{l}\text { Very sharp decrease in } \mu \text { over first } 40 \text { days. } \\
\text { (There was a slight increase at early time.) } \mu \\
\text { continued to decrease over entire time interval. } \\
\text { Overall, } \mu \text { decreased from } 58 \text { to } 27 \mathrm{cP} \text {. }\end{array}$ \\
\hline 0.40 & 10.73 & 9.58 & $0.5 \%$ XP- 100 & $\begin{array}{l}2000 \mathrm{ppm} \\
\text { Alcoflood } 1135\end{array}$ & 0.1 & $\begin{array}{l}\text { Very gradual decrease in } \mu \text { over entire time } \\
\text { interval. Very smooth curve. Overall, } \mu \\
\text { decreased from } 52 \text { to } 40 \mathrm{cP} \text {. }\end{array}$ \\
\hline 0.58 & 5.71 & 6.80 & 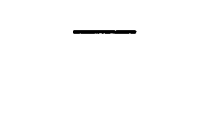 & $\begin{array}{l}2000 \mathrm{ppm} \\
\text { Alcoflood } 1135\end{array}$ & - & $\begin{array}{l}\text { Slight initial increase in } \mu \text {, then decreased } \\
\text { becoming stable. Overall, } \mu \text { decreased from } 34 \\
\text { to } 22 \mathrm{cP} \text {. }\end{array}$ \\
\hline 0.58 & 10.53 & 7.80 & - & 1135 & - & $\begin{array}{l}\text { Slight initial increase } \\
\text { becoming stable. Ov } \\
\text { to } 31 \mathrm{cP} \text {. }\end{array}$ \\
\hline 1.20 & 5.60 & 5.58 & - & d 1135 & - & $\begin{array}{l}\text { Slight increase in } \mu \text { at early time, then } \\
\text { decreased to a relatively stable value after } 60 \\
\text { days. Overall, } \mu \text { decreased from } 21 \text { to } 18 \mathrm{cP} \text {. }\end{array}$ \\
\hline 1.20 & 6.88 & 7.27 & $0.5 \%$ XP- 100 & $\begin{array}{l}2000 \text { ppm } \\
\text { Alcoflood } 1135\end{array}$ & - & $\begin{array}{l}\text { Very sharp initial decrease in viscosity. After } \\
40 \text { days, there was a slight increase in } \mu \text {. Then } \\
\mu \text { decreased for remainder of time interval. } \\
\text { Overall } \mu \text { decreased from } 25 \text { to } 8 \mathrm{cP} \text {. }\end{array}$ \\
\hline 1.20 & 6.87 & 7.25 & $0.5 \%$ XP-100 & $\begin{array}{l}2000 \mathrm{ppm} \\
\text { Alcoflood } 1135\end{array}$ & 0.1 & $\begin{array}{l}\text { Gradual, smooth decrease in } \mu \text { over entire time } \\
\text { interval, except for a slight increase in } \mu \text { over } \\
\text { first } 10 \text { days. Overall, } \mu \text { decreased from } 20 \text { to } \\
8 \mathrm{cP} \text {. }\end{array}$ \\
\hline 1.20 & 10.83 & 10.55 & - & - & - & $\mu=1.14 \mathrm{cP} @ 230 \mathrm{sec}^{-1}$ \\
\hline 1.20 & 10.50 & 8.33 & & $\begin{array}{l}2000 \mathrm{ppm} \\
\text { Alcoflood } 1135\end{array}$ & & $\begin{array}{l}\text { After an initial decrease in } \mu, \mu \text { was relatively } \\
\text { stable. Overall, } \mu \text { decreased from } 23 \text { to } 19 \mathrm{cP} \text {. }\end{array}$ \\
\hline 1.20 & 11.06 & 11.08 & XP-100 & & - & Stable dispersion. $\mu=1.22 \mathrm{cP} @ 230 \mathrm{sec}^{-1}$ \\
\hline
\end{tabular}


TABLE 2 - Continued

Mixtures of Polymer, Surfactant, and Brines Periodically Monitored for Changes in pH and Viscosity

\begin{tabular}{|c|c|c|c|c|c|c|}
\hline $\begin{array}{c}\text { Nacl } \\
\text { conc., } \\
\% \\
\end{array}$ & Initial & Final & $\begin{array}{c}\text { Surfactant, } \\
\% \\
\end{array}$ & Polymer & $\begin{array}{c}\text { Oil, } \\
\%\end{array}$ & Results \\
\hline 1.20 & 10.77 & 9.20 & $0.5 \%$ XP-100 & $\begin{array}{l}2000 \text { ppm } \\
\text { Alcoflood } 1135\end{array}$ & - & $\begin{array}{l}\text { Very sharp initial decrease in viscosity. After } \\
40 \text { days, there was a slight increase in } \mu \text {. Then } \\
\mu \text { decreased for remainder of time interval. } \\
\text { Overall } \mu \text { decreased from } 24 \text { to } 9 \mathrm{cP} \text {. }\end{array}$ \\
\hline 1.20 & 10.79 & 9.72 & $0.5 \%$ XP- 100 & $\begin{array}{l}2000 \mathrm{ppm} \\
\text { Alcoflood } 1135\end{array}$ & 0.1 & $\begin{array}{l}\text { Gradual, smooth decrease in } \mu \text { over entire time } \\
\text { interval, except for a slight increase in } \mu \text { over } \\
\text { first } 10 \text { days. Overall, } \mu \text { decreased from } 25 \text { to } \\
15 \mathrm{cP} \text {. }\end{array}$ \\
\hline
\end{tabular}




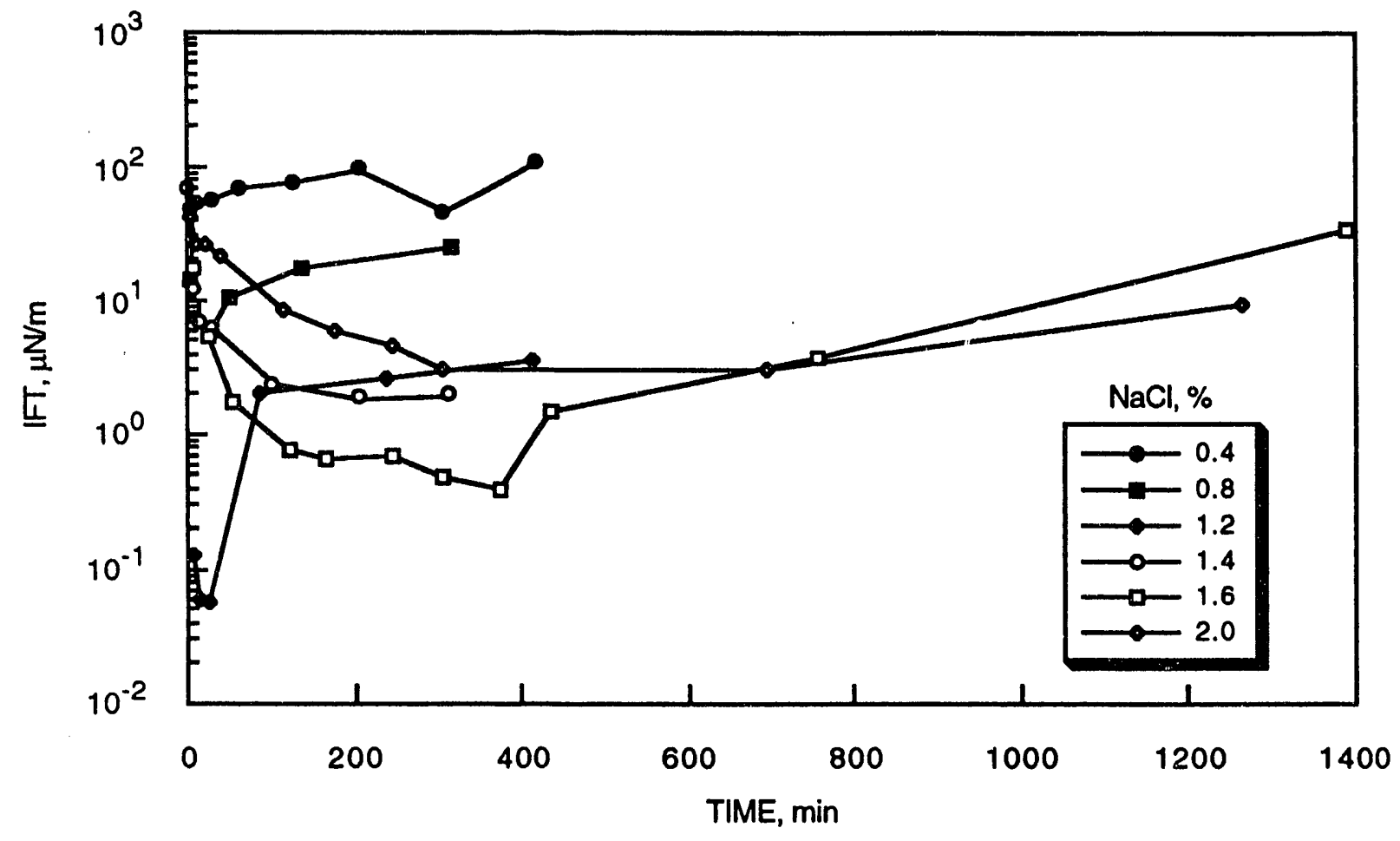

FIGURE 1. - Interfacial tension between $0.5 \%$ Chevron XP-100 surfactant, $\mathrm{NaCl}$, and Hepler (KS) crude oil, $23^{\circ} \mathrm{C}$.

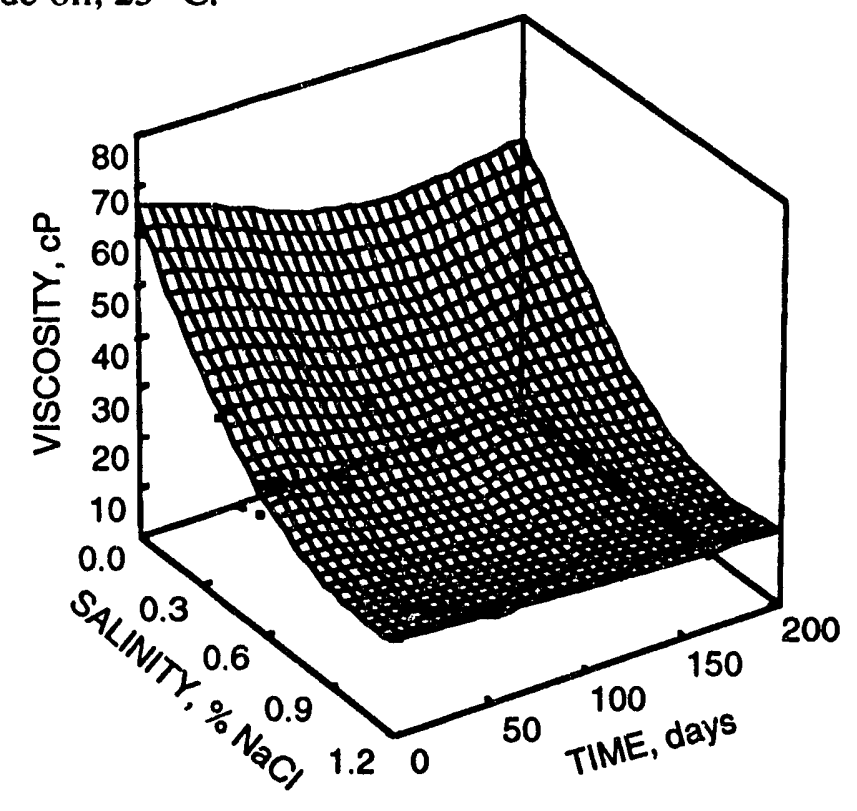

FIGURE 2. - Viscosity of non-alkaline mixtures of 2,000 ppm Alcoflood 1135 polymer and $\mathrm{NaCl}, 11.5 \mathrm{sec}^{-1}, 23^{\circ} \mathrm{C}$. 


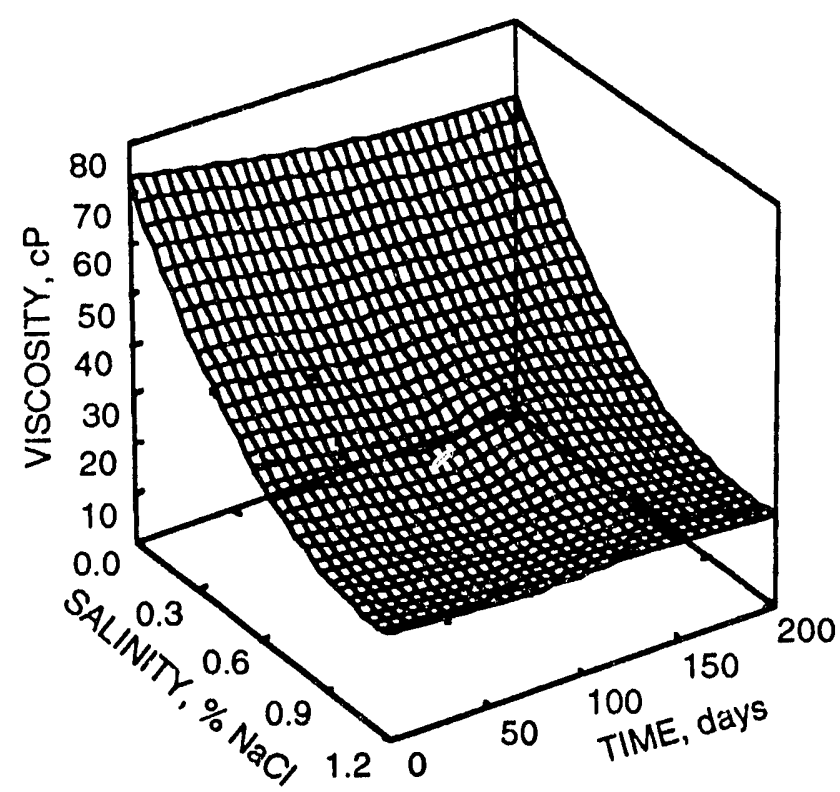

FIGURE 3. - Viscosity of alkaline mixtures of $2,000 \mathrm{ppm}$ Alcoflood 1135 polymer and $\mathrm{NaCl}$, $11.5 \mathrm{sec}^{-1}, 23^{\circ} \mathrm{C}$.

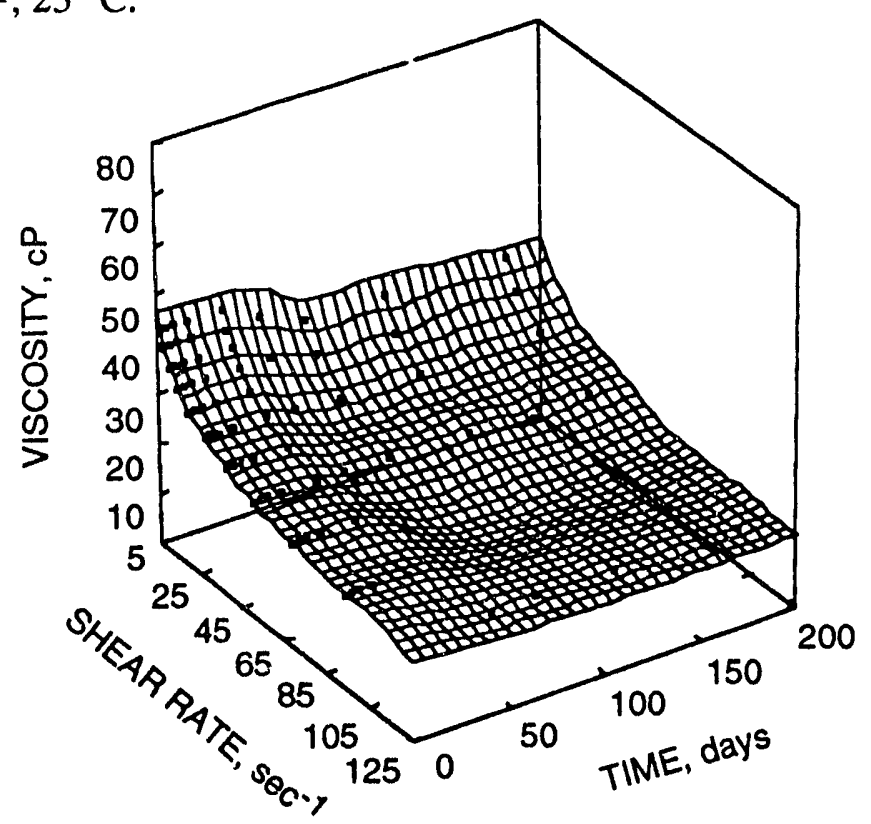

FIGURE 4. - Viscosity of 2,000 ppm Alcoflood 1135 polymer in $0.4 \% \mathrm{NaCl}, \mathrm{pH} 5.74,23^{\circ} \mathrm{C}$. 


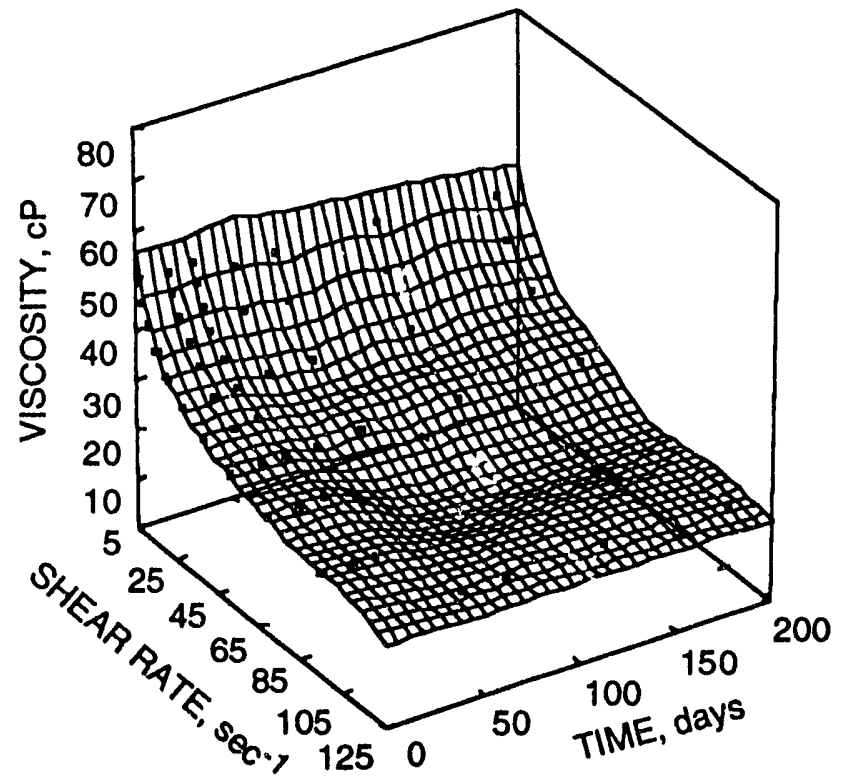

FIGURE 5. - Viscosity of 2,000 ppm Alcoflood 1135 polymer in $0.4 \% \mathrm{NaCl}, \mathrm{pH} 10.43,23^{\circ} \mathrm{C}$.

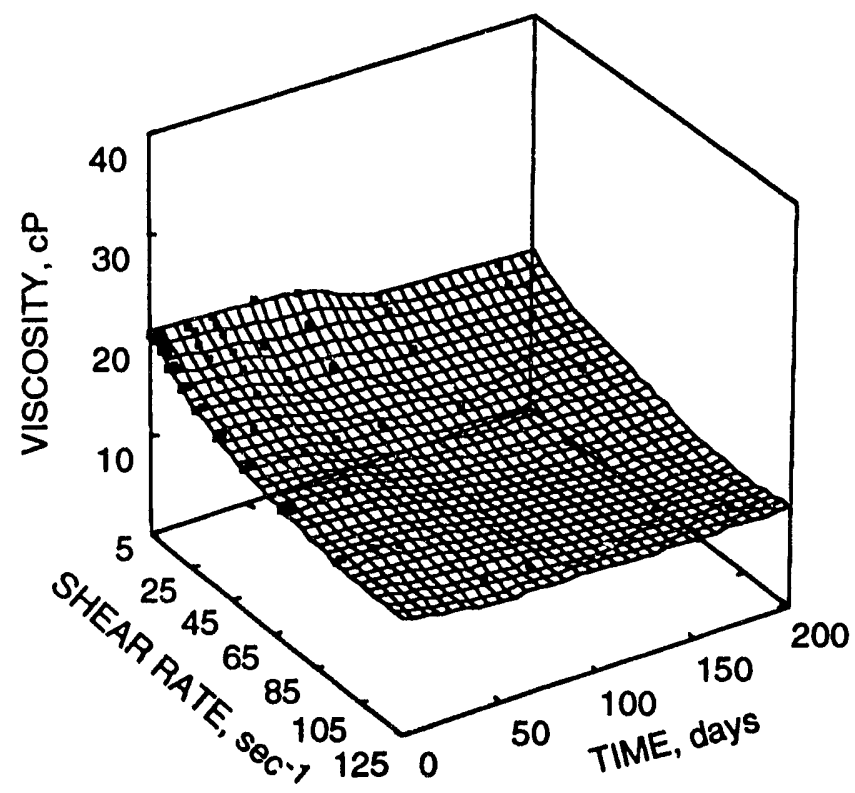

FIGURE 6. - Viscosity of $2,000 \mathrm{ppm}$ Alcoflood 1135 polymer in $1.2 \% \mathrm{NaCl}, \mathrm{pH} 5.60,23^{\circ} \mathrm{C}$. 


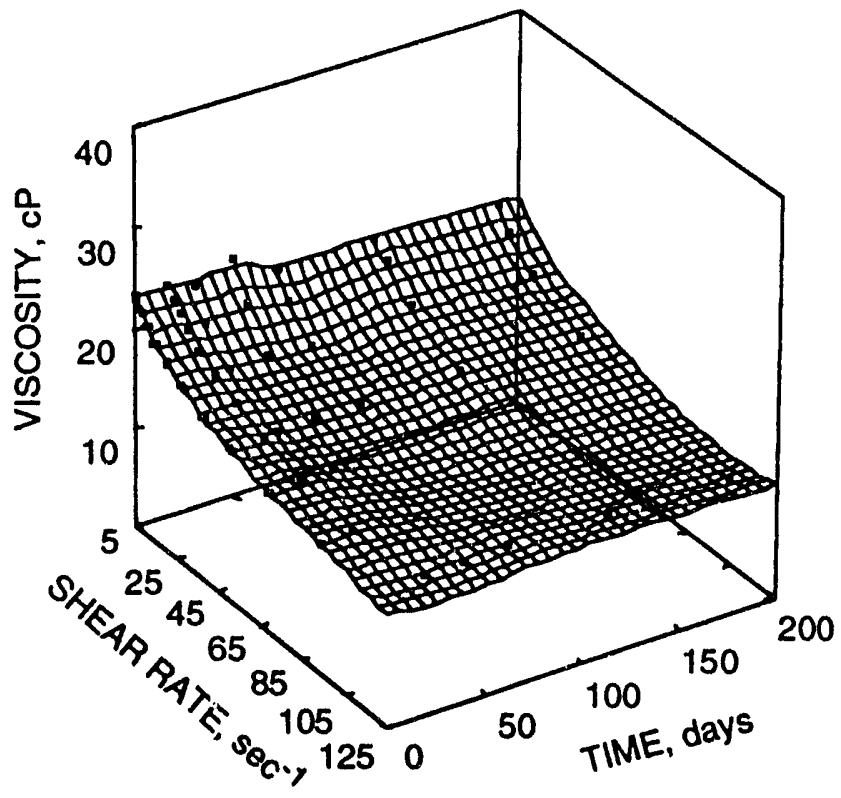

FIGURE 7. - Viscosity of 2,000 ppm Alcoflood 1135 polymer in $1.2 \% \mathrm{NaCl}, \mathrm{pH} 10.50,23^{\circ} \mathrm{C}$.

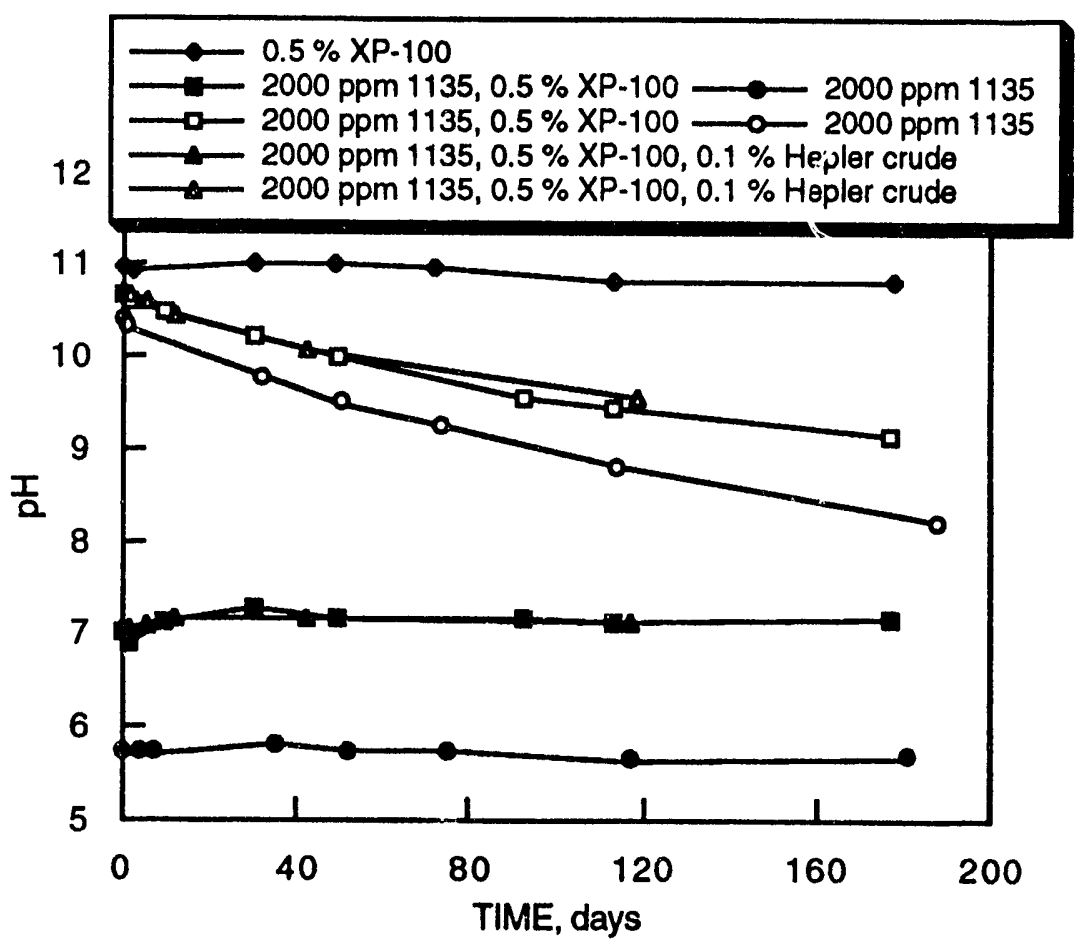

FIGURE 8. - The $\mathrm{pH}$ of mixtures of Alcoflood 1135 polymer and Chevron XP-100 surfactant in $0.4 \% \mathrm{NaCl}$. 


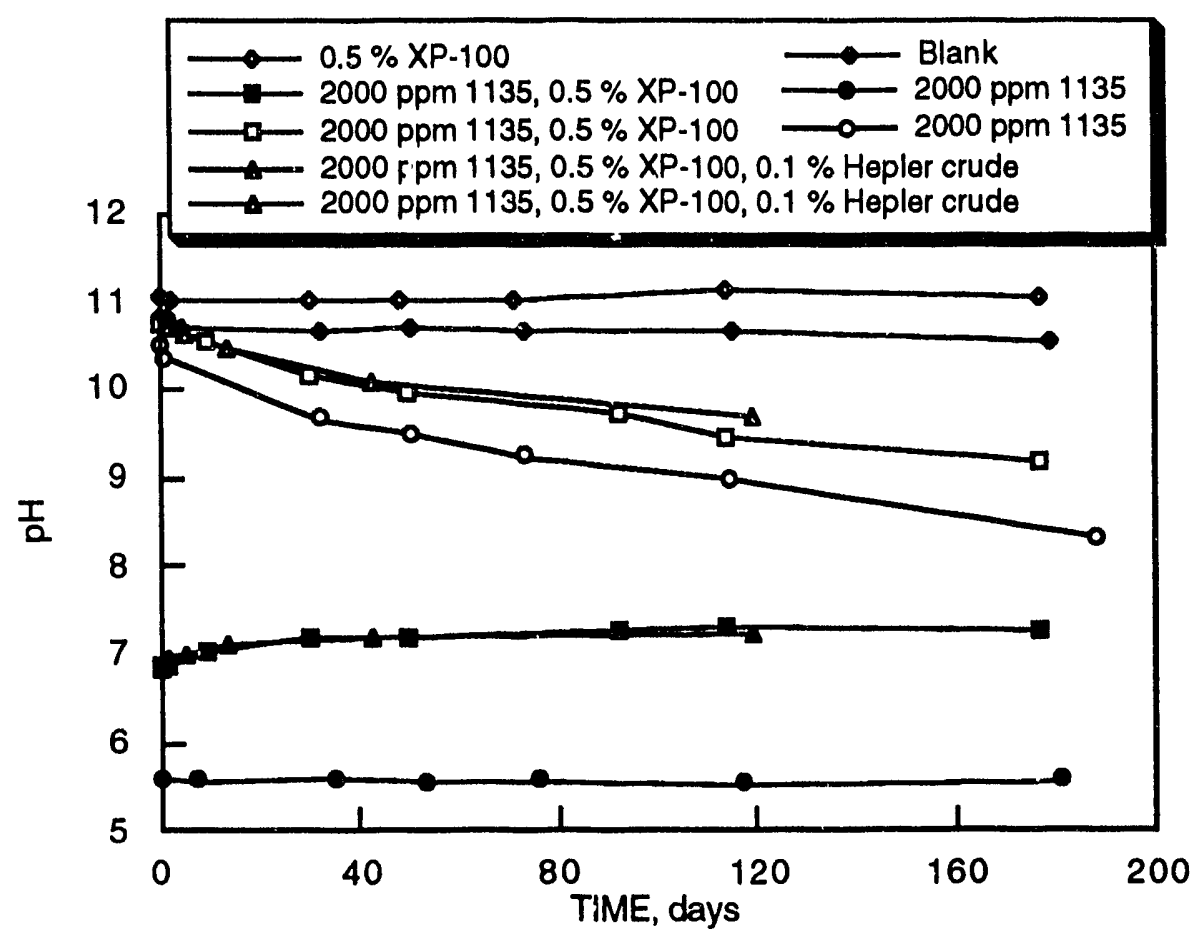

FIGURE 9. - The $\mathrm{pH}$ of mixtures of Alcoflood 1135 polymer and Chevron XP-100 surfactant in $1.2 \% \mathrm{NaCl}$.

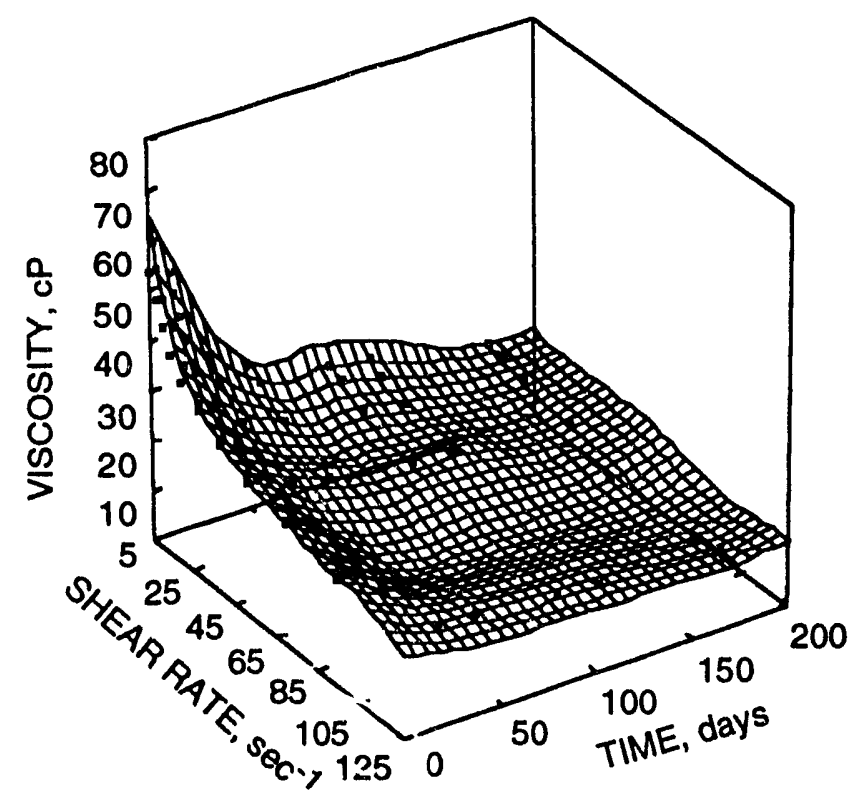

FIGURE 10. - Viscosity of 2,000 ppm Alcoflood 1135 polymer and $0.5 \%$ Chevron XP-100 surfactant in $0.4 \% \mathrm{NaCl}, \mathrm{pH} 7.04,23^{\circ} \mathrm{C}$. 


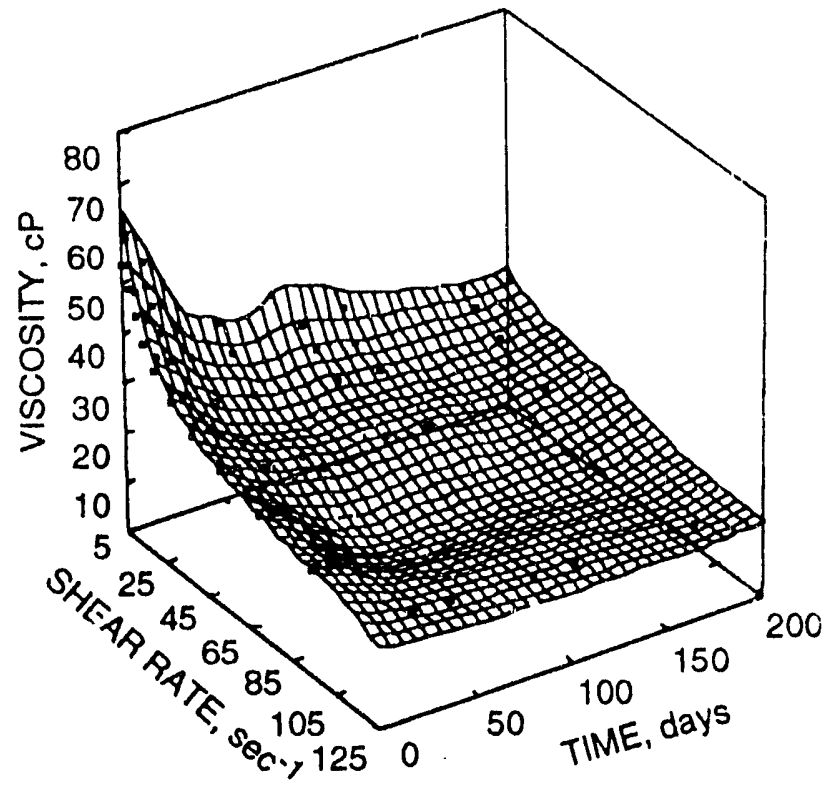

FIGURE 11. - Viscosity of 2,000 ppm Alcoflood 1135 polymer and 0.5\% Chevron XP-100 surfactant in $0.4 \% \mathrm{NaCl}, \mathrm{pH} 10.70,23^{\circ} \mathrm{C}$.

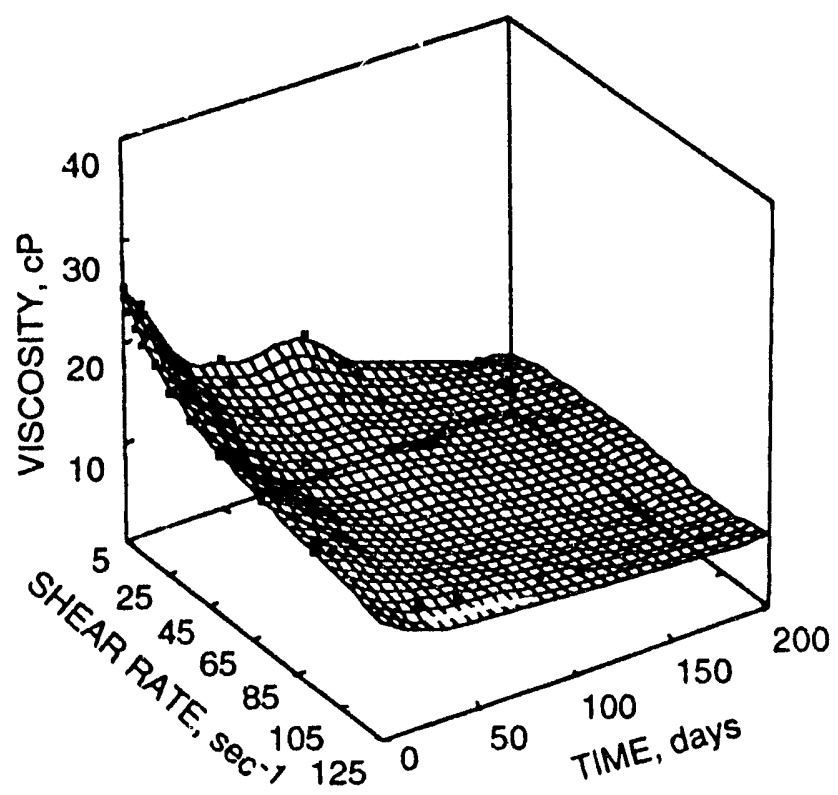

FIGURE 12. - Viscosity of 2,000 ppm Alcoflood 1135 polymer and $0.5 \%$ Chevron XP-100 surfactant in $1.2 \% \mathrm{NaCl}, \mathrm{pH} 6.88,23^{\circ} \mathrm{C}$. 


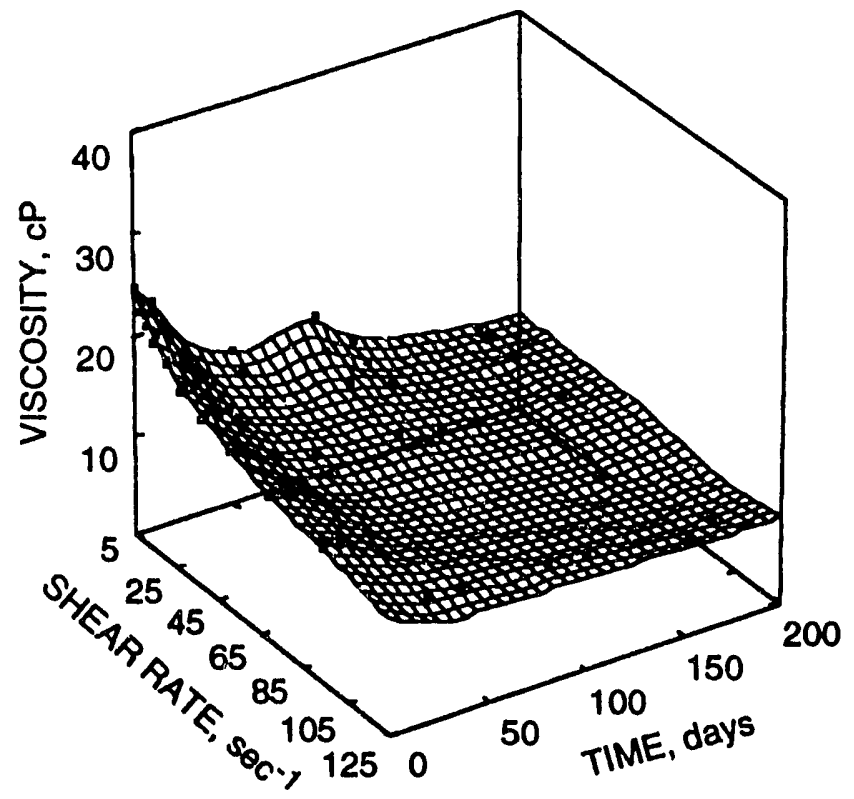

FIGURE 13. - Viscosity of 2,000 ppm Alcoflood 1135 polymer and $0.5 \%$ Chevron XP-100 surfactant in $1.2 \% \mathrm{NaCl}, \mathrm{pH} 10.77,23^{\circ} \mathrm{C}$.

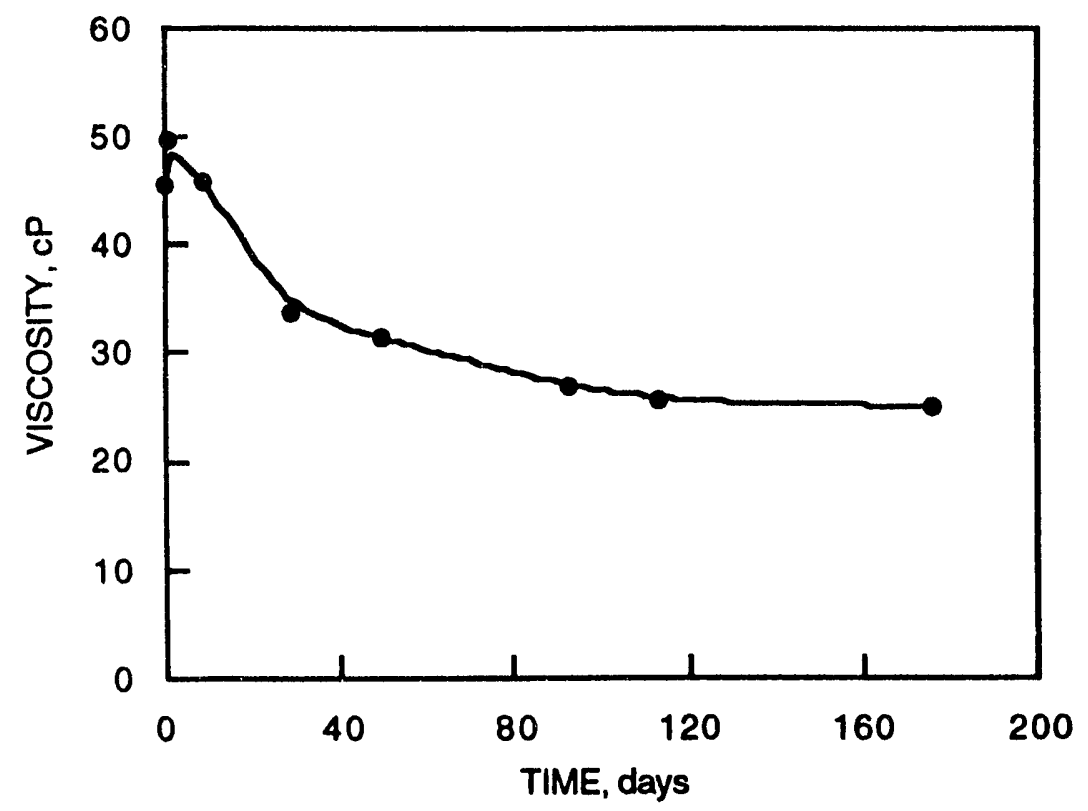

FIGURE 14. - Viscosity of 2,000 ppm Alcoflood 1135 polymer, and 0.5\% Chevron XP-100 surfac cant in $0.4 \% \mathrm{NaCl}, \mathrm{pH} 10.70,11.5 \mathrm{sec}^{-1}, 23^{\circ} \mathrm{C}$. 


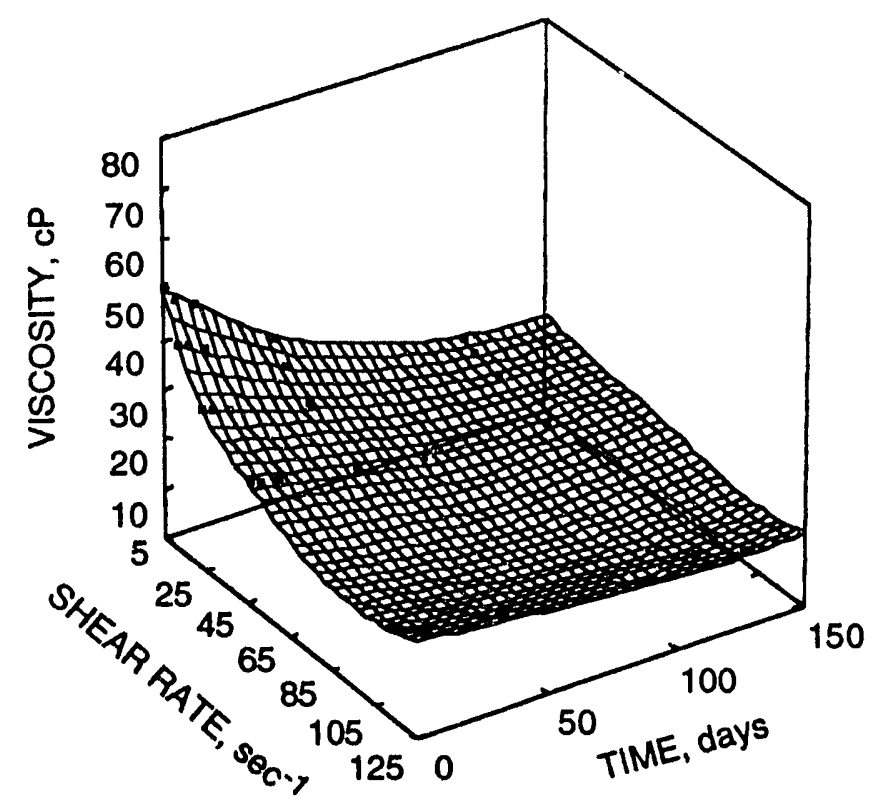

FIGURE 15. - Viscosity of 2,000 ppm Alcoflood 1135 polymer, $0.5 \%$ Chevron XP-100 surfactant, and $0.1 \%$ Hepler (KS) crude oil in $0.4 \% \mathrm{NaCl}, \mathrm{pH} 7.07,23^{\circ} \mathrm{C}$.

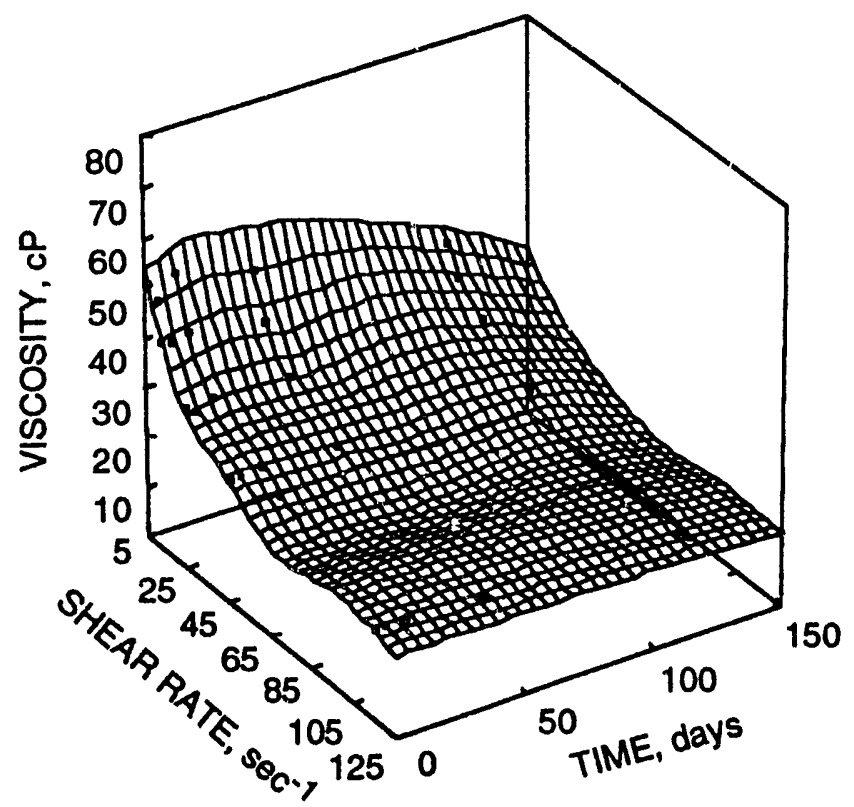

FIGURE 16. - Viscosity of 2,000 ppm Alcoflood 1135 polymer, $0.5 \%$ Chevron XP-100 surfactant, and $0.1 \%$ Hepler (KS) crude oil in $0.4 \% \mathrm{NaCl}, \mathrm{pH} 10.73,23^{\circ} \mathrm{C}$. 


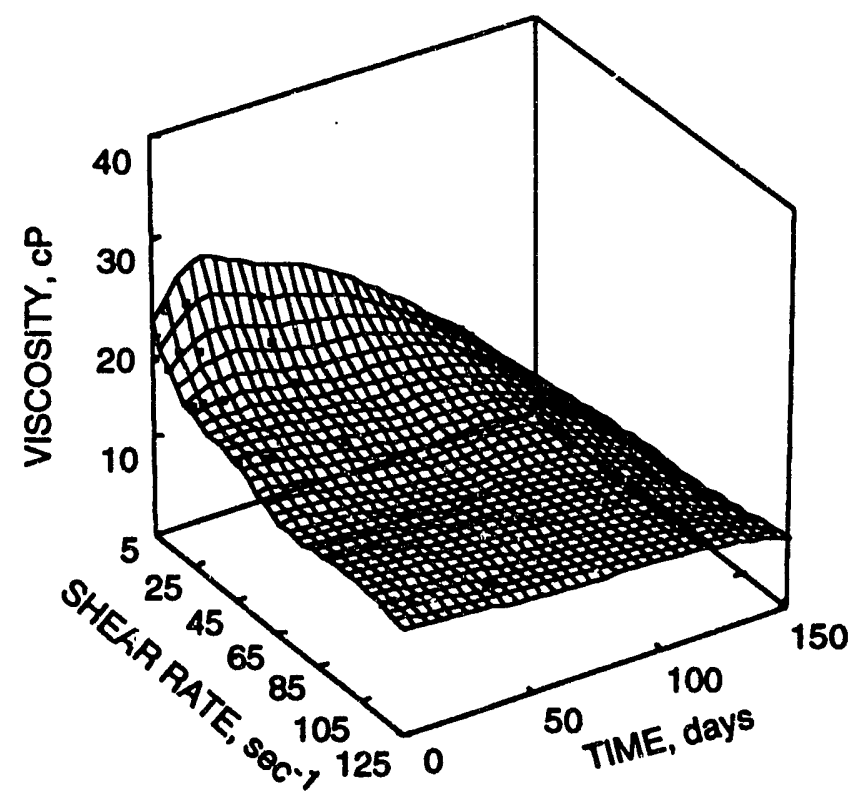

FIGURE 17. - Viscosity of 2,000 ppm Alcoflood 1135 polymer, $0.5 \%$ Chevron XP-100 surfactant, and $0.1 \%$ Hepler (KS) crude oil in $1.2 \% \mathrm{NaCl}, \mathrm{pH} 6.87,23^{\circ} \mathrm{C}$.

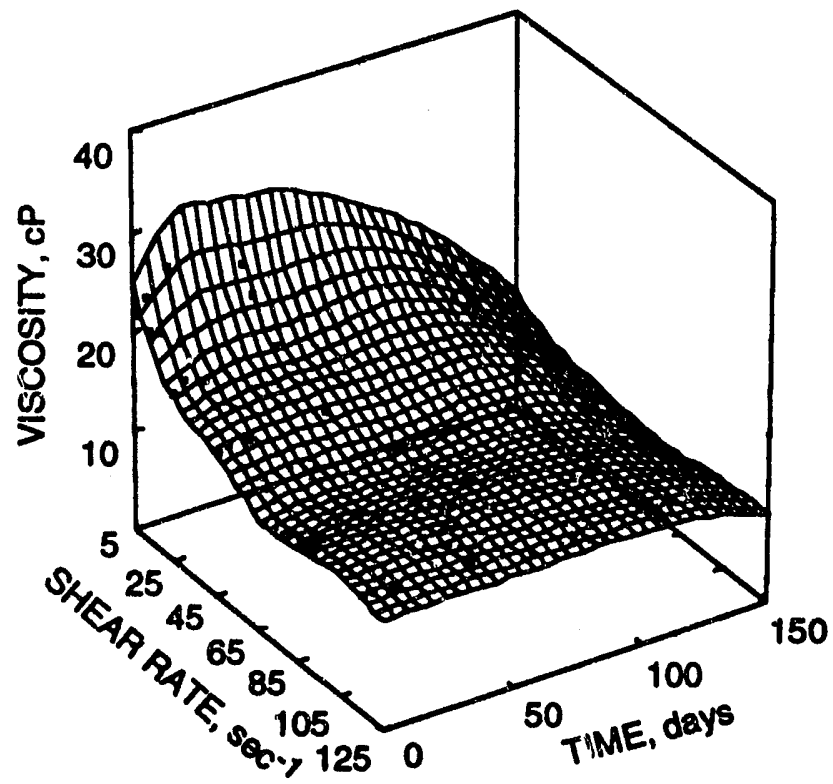

FIGURE 18. - Viscosity of 2,000 ppm Alcoflood 1135 polymer, $0.5 \%$ Chevron XP-100 surfactant, and $0.1 \%$ Hepler (KS) crude oil in $1.2 \% \mathrm{NaCl}, \mathrm{pH} 10.7923^{\circ} \mathrm{C}$.

*U.S.GPO: 1993-761-027/60075 

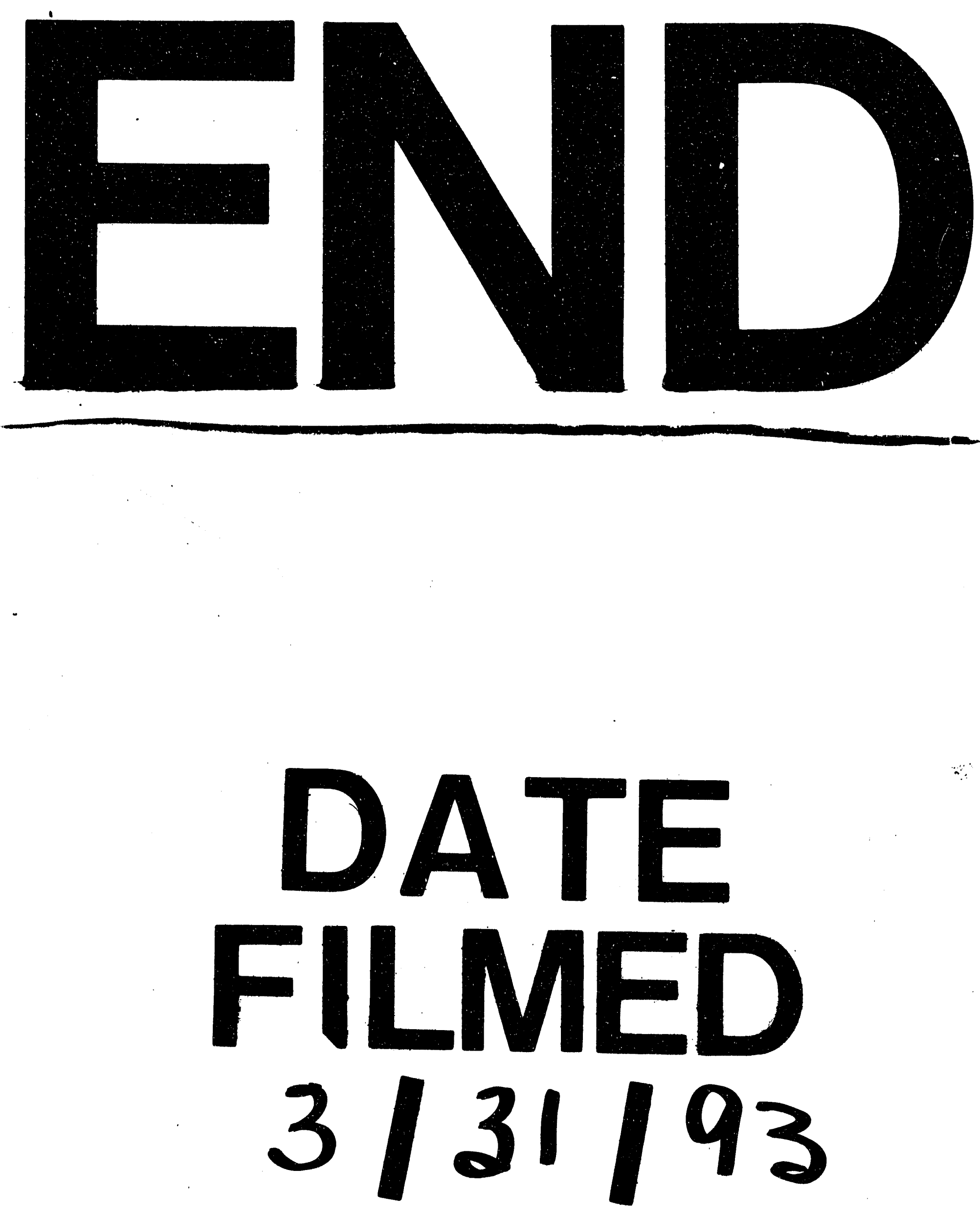
